\title{
Sosyal Medyada Kullanıcı Etkileşimi ve İçerik Kategorizasyonu: Ankara'daki Halk Kütüphanelerinin Facebook Gönderilerinin Analizi
}

\section{User Interaction and Content Categorization in Social Media: Analysis of Facebook Posts of Public Libraries in Ankara}

\author{
Tolga Çakmak* ve Şahika Eroğlu ${ }^{* *}$
}

\section{$\ddot{\boldsymbol{O}} \boldsymbol{z}$}

Etkileşim, paylaşım ve katılım gibi unsurlara dayanan sosyal medya platformlarında kütüphanelerin var olmaları hizmet sunumu ve pazarlamasinın yanı sıra kullanıc beklentilerinin belirlenmesine de katkl sağlayabilmektedir. Bu noktada kütüphanelerin sosyal medya platformlarında ürettikleri içerikler ve bu içeriklere yönelik olarak kullanıcılardan elde edilen etkileşim verileri etki değerlendirme amacıyla kullanılabilmektedir. Bu çalışmada Ankara'daki halk kütüphanelerinin yoğun olarak kullanılan sosyal medya platformlarından biri olan Facebook'taki kullanıcı etkileşiminin ve paylaştıkları gönderilerin konu dağılımının betimlenmesi amaçlanmaktadır. Çalışma kapsamında Ankara'daki 10 halk kütüphanesinin Facebook sayfalarındaki gönderiler toplanarak 1739 gönderi ve bu gönderilere ilişkin etkileşim verilerinden oluşan bir veri seti oluşturulmuştur. Veri seti üzerinde öncelikle betimsel analizler yapılmıştır. Sonrasında ise veri setindeki gönderilerin içerikleri metin madenciliği uygulamalart ile analiz edilmiştir. Bu analizler sonucunda gönderilere yönelik genel konu ve alt konu kategorileri belirlenmiştir. Elde edilen sonuçlar gönderilerde belirli kütüphanelerin Facebook sayfalarını aktif olarak kullandığını göstermiştir. Sonuçlar ayrıca etkinlik kategorisindeki gönderi içeriklerinin çoğunlukla çocuklar ile ilk ve ortaöğretim düzeyindeki kullanıcılara yönelik olduğunu ortaya koyarken, koleksiyona yönelik gönderi sayısının diğer kategorilere oranla daha az olduğunu yansıtmıştır. Sunulan sonuçlardan hareketle analiz edilen kütüphanelerin gönderilerinin etkileşim sayılarını artırmaları ve bu gönderileri hedef kitlelerine göre çeşitlendirmeleri gerektiği önerilmiştir. Buna ek olarak, kütüphanelerin koleksiyonlarına yönelik gönderi paylaşımlarını artırmalarına ihtiyaç duyulduğu da çalışmada vurgulanmıştır. Çalışmada son olarak kütüphanelerin sosyal medyadaki kullanıcı etkileşimini artırmak ve bu etkileşimin sürdürülebilirliği için bir sosyal medya stratejisi bağlamında hareket etmeleri gerektiği belirtilmiştir.

Anahtar Sözcükler: Halk kütüphaneleri; kullanıcı etkileşimi; sosyal medya; içerik analizi; Facebook.

\footnotetext{
* Dr. Öğr. Üyesi, Hacettepe Üniversitesi Bilgi ve Belge Yönetimi Bölümü. E-posta: tcakmak@ hacettepe.edu.tr Assistant Prof., Hacettepe University Department of Information Management, Turkey

${ }^{* *}$ Dr., Hacettepe Üniversitesi Bilgi ve Belge Yönetimi Bölümü. E-posta: sahikaeroglu@ hacettepe.edu.tr

Dr., Hacettepe University Department of Information Management, Turkey
} 


\section{Abstract}

The presence of libraries in social media platforms that mostly based on interaction, sharing, and engagement can contribute to the identification of user expectations as well as service delivery and marketing. In this regard, the content produced by libraries on social media platforms and the reaction data obtained from users can be utilized for impact assessment purposes. In this study, it is aimed to describe user interaction and to detect the content categories by analyzing the Facebook public page contents of public libraries in Ankara. Accordingly, 1739 posts and the interaction data related to these posts were collected on the Facebook pages of 10 public libraries in Ankara. The collected data were firstly presented with descriptive statistics, and then the posts were analysed by using text mining applications. Additionally, topics and sub-topics are detected. The results showed that specific libraries actively use their Facebook pages. It was also revealed in the study that the post contents in the event category were mostly for children and students at primary and secondary levels. The number of posts included in the collection category was lower than the number of posts in other categories. It is recommended in the study that the analyzed public libraries should develop more content according to their target audiences. It is also emphasized that the analyzed libraries should increase the number of post interactions, and they should increase the number of posts related to collections and services. Lastly, It was emphasized that the analyzed libraries should act in the context of a social media strategy to increase user interaction and provide its sustainability.

Keywords: Public libraries; user interaction; social media; content analysis; Facebook.

\section{Giriş}

Sosyal medya, iletişim teknolojilerinin gelişimi ile birlikte bireylerin düşüncelerini ve bu düşüncelerden üretilen çıktıları paylaşmak için yoğun olarak kullanılan ortamlardan birisi olmuştur. Bu ortamlar sosyal medya kullanıcıları arasındaki etkileşimi artırırken paylaşılan içeriğin geniş kitlelere ulaşması, bilgi alışverişi imkânlarını artırması gibi nedenlerle kurumlar tarafından da yoğunlukla kullanılan mecralar haline gelmiştir. Bu doğrultuda sosyal medyanın kurumlar tarafından geliştirilen hizmetleri ve ürünleri de hedeflenen kitlelere ulaşmada kullanılan bir iletişim kanalı olarak görülmeye başlanmıştır. Aynı zamanda kullanıcıların mobil cihazlarıyla zamandan ve mekândan bağımsız her ortamda rahatlıkla kullanabildikleri sosyal medya araçları, kurumlar için bazı durumlarda rekabet avantajı sağlayabilen stratejik bir etkileşim platformu olmuştur.

Kullanıcılarının bulunduğu sosyal medya ortamlarında yer alma konusunda girişimlerde bulunan kurumsal yapılardan biri olan kütüphaneler de sosyal medya platformlarını hizmet sunumu ve tasarımı için kullanmaktadır. Bu noktada birçok alanı etkileyen sosyal medyanın kütüphanecilik ve bilgibilim literatüründe "library 2.0", "OPAC 2.0" gibi kavramlar kapsamında çalışıldığı anlaşılmaktadır (Bughin, 2008; Chalon, Di Pretoro ve Kohn, 2008; Gavrilis, Kakali ve Papatheodorou, 2008). Kütüphanecilik ve bilgibilim alanında bu konuda yapılan çalışmalar kütüphanelerde sosyal medya araçlarının kullanımı, bilgi kaynaklarının ve bilgi hizmetlerinin pazarlanması, kullanıcı hizmetlerinin geliştirilmesi, iletişim süreçlerinin iyileştirilmesi, iş birliği, etkileşim gibi başlıklara yoğunlaşmıştır (Collins ve Quan-Haase, 2012; Fernandez, 2009; Solomon, 2013; Xu, Ouyang ve Chu, 2009). Dahası sosyal medya üzerinden 
kurumsal sayfalarını oluşturan kütüphanelerin bu platformlarda içerik geliştirmek ve geliştirilen içeriği en uygun şekilde kullanıcıya sunmak için politikalar geliştirdikleri de bilinmektedir. $\mathrm{Bu}$ doğrultuda kütüphanelerin de birçok kurumsal yapıda olduğu gibi sosyal medyadan en yüksek etkiyi elde etmeyi hedeflediklerini söylemek mümkündür.

Kütüphanelerin sosyal medya platformlarında ürettikleri içerikler aynı zamanda sunulan hizmetlere, tanıtımı yapılan konulara ve gerçekleştirilen etkinliklerle ilgili resmî olmayan bir kayıt havuzunun ve kurumsal hafızanın da oluşmasını sağlamaktadır. Kütüphanelerin kurumsal işleyişinde birçok resmi yazışma ile kayıt altına alınan hizmet ve etkinliklerin sosyal medya paylaşımlarıyla belirli bir bürokratik süreç olmaksızın ve daha ayrıntılı bir şekilde kayıt altına alınması mümkün olabilmektedir. Dahası bu veri havuzundan elde edilen veriler karar verme süreçlerinde etkili olabilmektedir. Bu doğrultuda uygun analiz teknikleri ile bu verilerden kurumsal değerler üretilebilmektedir.

Sosyal medya araçları içerisinde sosyal ağ siteleri özellikle de Facebook ve Twitter gibi platformlar yoğunlukla kullanılmaktadır. Kütüphaneler özelinde de değerlendirildiğinde bu platformların yoğun kullanımlarının olduğunu söylemek mümkündür. $\mathrm{Bu}$ doğrultuda kütüphanelerde bu iki platformun kullanımına ilişkin bilimsel çalışmalar da yapılmaktadır Konuyla ilgili literatür incelendiğinde farklı türdeki kütüphanelerin Facebook ve Twitter platformlarındaki gönderi içeriklerinin analiz edildiği ve etkileşim örüntülerinin tespit edildiği görülmektedir (Aharony, 2010, 2012; Chen, Chu ve Xu, 2012; Wright Joe, 2015). Kullanıc1 etki değerlendirmelerinde önemli bir yere sahip olan bu çalışmaların farklı kütüphane türlerinde yapılandırılması gerekliliği çalışmamızın motivasyonunu oluşturmaktadır.

Çalışmada geniş bir kullanıcı kitlesine sahip olan halk kütüphanelerinin hizmetlerine yönelik kullanıcı etkileşimlerinin Facebook sayfalarındaki gönderiler kapsamında analiz edilmesi amaçlanmıştır. Bu doğrultuda 42 halk kütüphanesi bulunan Ankara'daki halk kütüphanelerinden Facebook’ta sayfası bulunan 10 halk kütüphanesi araştırma kapsamına alınmıştır.

Çalışmanın birinci bölümünde öncelikle sosyal medya ve kütüphanelere yönelik kavramsal tanımlamalar literatür çerçevesinde açıklanmış ve kütüphanelerde sosyal medya kullanımı çalışmaları irdelenmiştir. Sonrasında çalışmada kullanılan yöntemler açıklanmıştır. Ardından halk kütüphanelerinin gönderilerine yönelik veriler ile etkileşim verileri tanımlayıcı istatistiklerle sunulmuştur. Ardından da gönderilerin içerikleri analiz edilmiştir. Çalışmanın son bölümünde ise Ankara'daki 10 halk kütüphanesinin Facebook sayfalarındaki içeriklerin konu kategorilerine göre dağılımı ve etkileşim oranlarına ilişkin sonuçlara yer verilerek değerlendirmeler yapılmıştır.

\section{Sosyal Medya ve Kütüphaneler}

Sosyal medya, 2000'li yılların başlarından itibaren ortaya çıkan ve birçok sektörü etkileyen bir ortamdır. Gartner tarafından yayınlanan Bilgi Teknolojileri sözlügünde sosyal medya, içeriğin öncelikli olarak topluluklar ve etkinlikler için üretildiği, pazarlandığı, dağıtıldığı, paylaşıldığ ve tüketildiği çevrimiçi bir ortam olarak tanımlanmıştır. Sözlükteki tanımda yer alan kavramlardan medya, içeriğin depolanması ya da aktarılmasını, sosyal ise içeriğin yayılma biçimini ifade etmektedir ("Social Media", 2019). Bir diğer tanıma göre ise sosyal medya kavramsal olarak sosyal ağ sitelerinde insanların farklı amaçlara (içerik paylaşımı, anlık 
mesajlaşma, konum tabanlı hizmetler, oyunlar gibi) yönelik olarak kullanabilecekleri uygulama ve teknolojiler şeklinde de ifade edilebilmektedir (Albarran, 2013, s. 2).

Genel olarak değerlendirildiğinde sosyal medya toplumun iletişim kurma, öğrenme ve iş geliştirme gibi süreçlerini değiştirmiştir (Lewis ve Nichols, 2013). Bu doğrultuda kurumların sosyal medyayı kullanarak hizmet verdikleri kitlelerle etkileşimlerini artırma yoluna girdikleri görülmektedir. Stratejik iletişim bir kurumun misyonunu yerine getirebilmesi için iletişimi amaca yönelik kullanması olarak tanımlanmakta ve kurumun genel stratejisi ile uyumlu bir işleyişi temsil etmektedir. Bu iletişim reklam, halkla ilişkiler ve pazarlama gibi uygulamaları içermektedir (Hallahan, Holtzhausen, van Ruler, Verčič ve Sriramesh, 2007). Sosyal medya ortamında bulunan kitlelerin gönüllü olarak bir kurumu ya da hizmeti takip etmesi, beğenmesi veya arkadaş olarak eklemesi, kurumlar için güvenilir bir topluluğun oluşmasını sağlamaktadır.

Kurumların sosyal medya ortamı olarak en çok kullandıkları platformlardan biri Facebook'tur. Facebook'un benzer ilgilere sahip kullanıcılara ulaşmayı sağlayan yapısı kurumların bu platform üzerinde sayfa oluşturmalarında etkili olmaktadır (Long, 2013). Facebook'un 100 milyon kullanıcıya yaklaşık dokuz aylık bir sürede ulaştığı bilinirken, radyo ve televizyon gibi geleneksel medya ortamlarının 10 yıldan uzun bir sürede 50 milyon kullanıcıya ulaşabildiği belirtilmektedir (Patel, 2010).

Teknolojik gelişmelerin yanı sıra küreselleşme ve toplumlarda çok kültürlülüğün artışı, politik ve ideolojik değişiklikler kütüphanelerin hizmetlerini çeşitlendirmelerinde etkili olmuştur (Evjen ve Audunson, 2009). Sosyal medya kütüphaneler için hizmet sunumu ve kullanıcılara ulaşma bağlamında öne çıkan bir iletişim kanalı olarak dikkat çekmektedir. Kütüphanelerin sosyal medya üzerinden kullanıcılarla etkileşimleri bilgi paylaşımı, kullanıcılarla diyalog ve kullanıcı görüşlerini alma şeklinde olabilmektedir (Chen ve diğerleri, 2012). Bunun yanı sıra sosyal medya araçlarının kütüphanelerde yapılandırılmasında kütüphanelerin bazı unsurları göz önünde bulundurmaları gerektiği belirtilmektedir. Bu unsurlar (Wright Joe, 2015);

- Sosyal medya ile gerçekleştirilecek amaçlara karar vermek,

- Hangi sosyal medya aracının ya da platformunun kurum için etkili olacağına karar vermek için ön çalışma yapmak,

- Kullanılacak sosyal medya platformuna ve yapılandırma planına karar vermek,

- Değerlendirme planının yapılması ve sosyal medya araçlarının kullanımıyla hedeflenen amaçlara ulaşılması ile ilgili en iyi değerlendirme aracını saptamak,

- Seçilen değerlendirme aracının kullanımıyla birlikte elde edilen sonuçları analiz etmek ve sosyal medya yapılandırma sürecini gereksinimlere göre yeniden düzenlemektir.

Sosyal medya halk kütüphanelerinde iletişim ve anlık mesajlaşma, içerik paylaşımı, bir takipçi kitlesi oluşturma ya da bir diğer deyişle bir topluluk oluşturma, hizmetlere yönelik geri bildirim alma, farkındalık oluşturma, yeni kullanıcılara ulaşma ve kitle kaynak yoluyla içerik oluşturma, kullanıcılarca geliştirilen içerikten yararlanma gibi amaçlarla kullanılmaktadır (Anttiroiko ve Savolainen, 2011; Blakeman ve Brown, 2010). Bunun yanı sira sosyal medya kütüphaneler için bilgi kaynaklarının tanıtımı ve bilgi hizmetlerinin pazarlanmasında aktif bir rol oynamakta, kütüphanecilerle kullanıcılar arasındaki etkileşimi farklı boyuta taşımakta, bilginin ve gelişmelerin duyurulmasında kullanılmakta ve kütüphaneden haberdar olmayan kullanıcılarla etkileşim kurmada da değer taşımaktadır (Collins ve Quan-Haase, 2012). Sosyal 
medya birçok sektörde olduğu gibi kütüphaneler için de sunulan hizmetlere yönelik geri bildirim alma açısından da önemli bir araçtır. Bu çerçevede dinamik bir kullanıcı kitlesinin oluşturulması, değişen kullanıcı beklentilerini anlama ve düşük maliyetle kullanıcı etkileşimi sağlama gibi olanaklar sunmaktadır (Fernandez, 2009). Bu özelliklerin yanı sıra sosyal medyanın kütüphanelerde Web 2.0 teknolojilerindeki açıklık, etkileşim, yakınsama, iş birliği ve katılımcılık gibi unsurları da sağladığı ifade edilmektedir (Xu, Ouyang ve Chu, 2009). Sosyal medya aynı zamanda kütüphaneler için kullanıcılarla yüz yüze iletişimden sonra doğrudan geri bildirim almayı sağlayan en etkili araç olarak gösterilmektedir (Solomon, 2013).

Literatürde, sosyal medyanın kütüphanelerde kullanımının SWOT analizi ile de değerlendirildiği görülmektedir. Bu çerçevede yapılan bir çalışmada kütüphanelerin sosyal medya konusundaki güçlü yönleri; sosyal medya sitelerinin çoğunlukla ücretsiz olması, kolay bir kurulum altyapısı sunması, kısa süre içerisinde geniş kitlelere ulaşım sağlayabilmesi, kullanıcıların hizmetlere ilişkin görüş bildirebilme ve içeriğe kontrolüne imkân tanıması, kütüphanecileri daha geniş kapsamda düşünmeye yöneltmesi olarak açıklanmaktadır (Fernandez, 2009). Aynı çalışmada sosyal medyanın kütüphaneler için sağladığı firsatlar geniş kitlelere ve yeni kullanıcılara ulaşma, bilgi hizmetlerini pazarlama, hizmetlere yönelik geri bildirim alma şeklinde ifade edilmiştir. Diğer yandan kütüphanelerin sosyal medya konusunda zayıf olduğu noktalar da sosyal medya platformlarının tasarım açısından sınırlılıklarının olması, paylaşılan bilginin karakter sınırı gibi bir limitle sınırlanabilmesi, bazı sosyal medya araçlarının ek kurulum gerektirebilmesi ve kütüphanelerin eleştiriye açık olmamalarıdır. SWOT analizindeki son bileşen olan tehditler bölümünde ise sosyal medya platformlarının kötü niyetli kullanıma açık olabilecek yapıları, denetime yönelik güçlükler ve kullanıcıların çok kolay bir şekilde etkileşimden ayrılabilmeleri yer almaktadır.

2015 yılında Çin, Hong Kong, Tayvan, Amerika, Birleşik Krallık, Avustralya ve Yeni Zelanda'dan seçilen 110 kütüphanenin sosyal medya kullanımlarının incelendiği araştırmada halk kütüphanelerinin karşılaştığı sorunlar; personel yetersizliği, paylaşımların zaman alıcı olması, yaşatım sorunları, politika eksikliği, kullanıcı katılımını sağlamada ve etki değerlendirmedeki zorluklar olduğu saptanmıştır (Abdullah, Chu, Rajagopal, Tung ve KwongMan, 2015, s. 42).

Birçok sosyal medya aracını kütüphane için yapılandırmanın mümkün olmasına karşın kullanıcı etkileşiminin bu araçlar üzerinden olmaması yatırımın ya da girişimin istenen verimliliğe ulaşamamasına neden olabilmektedir. $\mathrm{Bu}$ doğrultuda kütüphanecilerin yapılandırdığı araçlarla kullanıcıların etkileşimde tercih ettikleri araçların farklılık gösterdiğini ortaya koyan araştırmalar bulunmaktadır (Kim ve Abbas, 2010). Konuyla bağlantılı olarak kütüphanelerin popüler sosyal medya araçlarını yapılandırma yerine kullanıcılara uygun etkileşim düzeyi ve kalitesi sunan araçları bir araya getirme çabasında olmaları önerilmektedir (Anttiroiko ve Savolainen, 2011).

Genel olarak kütüphanelerde sosyal medya hizmetlerinin değerlendirilmesi ile ilgili çalışmalar incelendiğinde konunun dört kategoride ele alındığını söylemek mümkündür. Bu kategorilerden ilki kütüphaneler ve kütüphanecilerin kütüphanelerde sosyal medya araçlarının yapılandırılmasına yöneliktir. $\mathrm{Bu}$ kapsamda kütüphanelerde sosyal medya araçlarının kullanımıyla elde edilecek faydalar, olası tehdit ve sorunlar, topluluk oluşturmaya yönelik modellemeler ile kütüphanecilerin yaklaşımlarının ele alındığı görülmektedir (Bodnar ve 
Doshi, 2011; Fernandez, 2009; Young ve Rossmann, 2015; Zohoorian-Fooladi ve Abrizah, 2014). İkinci kategoride kullanıcıların analiz edildiği araştırmalar yer almaktadır (Kim ve Abbas, 2010; Kronqvist-Berg, 2014). Üçüncü kategoride ise kütüphanelerin sosyal medya platformlarında ürettikleri içerikleri analiz eden çalışmalar bulunmaktadır. Bu çalı̧̧alarda kütüphanelerin sosyal medyayı nasıl kullandıkları ve etkileşim analizleri gibi ayrıntılar yer almaktadır. Ek olarak literatürde yukarıda belirtilen kategorilerin ikisini ya da üçünü kapsayan çalışmaların da yapıldığı bilinmektedir.

Kütüphanelerin sosyal medya platformlarında ürettikleri içeriği analiz eden çalışmaların genellikle Facebook ve Twitter platformlarına odaklandığı görülmektedir. Bu kapsamda halk kütüphaneleri ve üniversite kütüphanelerinin bu platformlarda kullandıkları dil ve anlatım, platformu kullanım amaçları gibi noktalar incelenmiştir. Twitter verisinin analiz edildiği araştırmada halk kütüphanelerinin üniversite kütüphanelerine göre daha resmi olmayan bir dili tercih ettiği, bu platform üzerinden duyurular, yönlendirmeler ve kütüphane hizmetleri hakkında bilgilendirmelerde bulunduğu anlaşılmıştır (Aharony, 2010). Twitter'da kütüphanelerin ürettiği içeriği analiz eden bir diğer çalışma ise Edmonton Halk Kütüphanesine yönelik olarak yapılmıştır. 2500 twit üzerinden yapılan inceleme kütüphanenin teşekkür mesajları, yönlendirme hizmetleri, etkinlikler etkinliklerle ilgili gönderiler paylaştığını ortaya koymuştur. Çalışmadaki bulgular ayrıca kütüphanelerin, geri bildirim alma gibi amaçlarla da gönderi paylaştıklarını yansıtmıştır (Shiri ve Rathi, 2013).

Üniversite ve halk kütüphanelerinin Facebook kullanımlarının karşılaştıııldı̆̆ı araştırmalar da literatürde yer almaktadır. Bu doğrultuda yapılmış bir çalışmada Facebook platformunu kullanan on üniversite ve on halk kütüphanesi hem profil bilgileri, hem de paylaştıkları içerik açısından incelenmiştir (Aharony, 2012). Araştırma sonuçlarında halk kütüphanelerinin fotoğraflar ve duvar bölümlerini üniversite kütüphanelerine göre daha yoğun kullandıkları ve paylaşılan içerik açısından iki kütüphane türünün de farklılık gösterdiği anlaşılmıştır. Sonuçlarda ayrıca üniversite kütüphanelerinin sırasıyla kütüphane koleksiyonu, kütüphane hizmetleri ve teknoloji kategorilerinde, halk kütüphanelerinin ise sirasıyla kütüphane aktiviteleri, kütüphane hizmetleri ve kütüphanenin genel durumu ile ilgili paylaşımlarda bulunduğu vurgulanmıştır. Benzer araştırmalar Facebook üzerinde de yapılmıştır. Bu kapsamda 151 halk kütüphanesinin verilerine dayanılarak yapılan bir araştırmada metin madenciliği uygulamalarından yararlanılmış ve halk kütüphanelerinin gönderilerinde uygulanan programlar, duyurular ve kütüphane etkinliklerine yönelik kelimelerin bulunduğu tespit edilmiştir (Joo ve Lu, 2017). Ayrıca gönderilerin çoğunlukla çocuklara ve genç yetişkinlere yönelik olduğu da araştırmada saptanan bir diğer dikkat çekici bulgudur. 151 halk kütüphanesi üzerinde gerçekleştirilen bir diğer araştırmada da kütüphanelerin Facebook sayfalarındaki paylaşımlarda daha çok yakın zamanda yapılacak olan etkinliklere yönelik bilgilere yer verildiği anlaşılmışır (Joo, Choi ve Baek, 2018). Araştırma içerik türü olarak fotoğrafların etkileşim oranlarının daha yüksek olduğunu ortaya koymuştur. Buna ek olarak söz konusu araştırmada haberlerin ve duygusal açıdan etkileyici mesajların daha yüksek etkileşim sağladığı sonucuna ulaşılmıştır. Literatürde kütüphanelerin Facebook paylaşımlarında gönderi türü olarak fotoğrafları ya da multimedya paylaşımlarını tercih etmelerinin ve gönderi sıklığının kullanıcı etkileşiminde belirleyici olduğuna da değinilmektedir (Houk ve Thornhill, 2013). Bu durumun tam tersine gönderi sayısının düşük 
olmasına karşın yüksek takipçi sayısına sahip olan kütüphanelerin de olduğu bilinmektedir (Winn, Rivosecchi, Bjerke ve Groenendyk, 2017). Bunların yanı sıra çok uluslu bir araştırmada da üniversite ve halk kütüphanelerinin Facebook, Twitter ve Weibo gibi sosyal medya platformlarındaki etkinliklerinden hareketle kütüphanelerin kullanıcı kitlelerinin özelliklerine göre birden çok sosyal ağ sitesini koordine etmeleri gerektiği sonucuna ulaşılmıştır (Chen ve diğerleri, 2012).

Kütüphanelerin sosyal medya kullanımına yönelik çalışmalar Türkiye'deki kütüphaneler üzerinde de yapılmıştır. Bu kapsamda kütüphanelerin sosyal medya kullanım tercihleri, sosyal medya politikalarının yapılandırılması ve kütüphanecilerin yaklaşımları konunun kütüphane ve kütüphaneci yaklaşımları boyutunda ele alınmıştır (Akbaş ve Fenerci, 2016; Aras, 2014; Aras ve Çolaklar, 2015; Özel, 2018; Tavluoğlu, 2013). Türkiye'de konuyla ilgili çalışmalarda kullanıcıların yaklaşımları da ampirik veriye dayalı olarak sunulduğu dikkati çekmektedir. $\mathrm{Bu}$ çerçevede yapılan bir araştırmada kullanıcıların kütüphanelerin Facebook ve Twitter ortamında görülebilir olmalarına yönelik beklentilerinin olduğu tespit edilmiştir (Yalçın, 2014). Kütüphanelerin sosyal medya verilerinin analizi boyutunda ise Türkiye'deki kütüphanelerin paylaşımlarının konusal dağılımını ele alan bir içerik analizine rastlanmamıştır. Ancak bu konuya yakınsayan bir çalışma olarak Ankara'daki yedi üniversite kütüphanesinin Twitter profillerini ve içeriklerinin incelendiği görülmüştür. Bu araştırmaya göre gönderi sayısı fazla olan ve gönderilerinde daha fazla etiket kullanan kütüphanelerin takipçi sayılarının yüksek olduğu sonucuna ulaşılmıştır (Keleş, 2017).

\section{Yöntem}

Çalışmada Ankara'daki halk kütüphanelerinin kullanıcı etkileşimlerinin resmi Facebook sayfalarında paylaşılan gönderiler üzerinden analiz edilmesi amaçlanmıştır. $\mathrm{Bu}$ amaç doğrultusunda araştırmada Ankara'daki 10 halk kütüphanesinin Facebook sayfalarındaki gönderiler ve gönderilere yönelik kullanıcı etkileşimlerini gösteren nicel ve nitel veriler incelenmiştir. $\mathrm{Bu}$ noktada çalışmada iki yöntemin kullanıldığını söylemek mümkündür. Bunlardan ilki gönderilere ilişkin verilerin (paylaşım zamanları, gönderi türleri ve etkileşim şekilleri) tanımlayıcı istatistiklerle sunulmasıdır. İkinci yöntem ise içerik analizidir. İçerik analizi metinlerden ya da diğer ortamlardaki kayıtlı bilgilerden tekrarlanabilir ve doğrulanabilir çıkarımlar yapmaya dayanan bir araştırma tekniğidir (Krippendorff, 2004, s. 18). Bu çerçevede halk kütüphanelerinin metin tabanlı içeriğe sahip gönderileri kategorilere ayrılmıştır. Sonrasında söz konusu gönderiler standartlaştırılmış ve metin madenciliği uygulamalarıyla da nicel veriler halinde sunulmuştur. Araştırmada belirtilen yöntem ve teknikler doğrultusunda şu sorulara yanıt aranmıştır:

S1: Ankara'daki halk kütüphanelerinin Facebook gönderilerine ilişkin kullanıcı etkileşimi ne şekilde (beğeni, yorum, paylaşım bazında) gerçekleşmektedir?

$S 2$ : Ankara' daki halk kütüphanelerinin hangi zaman dilimlerindeki gönderileri daha fazla etkileşim almaktadır?

S3: Ankara'daki halk kütüphaneleri Facebook'ta hangi konular ve alt konularda paylaşımda bulunmaktadır?

Bu doğrultuda araştırma ilgili halk kütüphanelerinin Facebook sayfalarındaki ve yalnızca kendilerinin paylaştığı gönderi ve etkileşim verileriyle sınırlandırılmıştır. 


\section{Veri Toplama Süreci}

Araştırmada verilerin elde edilmesi için öncelikle Ankara'daki halk kütüphanelerinin Facebook'taki resmî sayfalarının adresleri tespit edilmiştir. Ardından her sayfa için Facebook tarafından verilen tekil ID bilgileri kaydedilmiştir. Sayfalara yönelik ilk incelemelerde iki kurumun sayfasında yalnızca bir gönderinin bulunduğu, bazı kütüphanelerin sayfalarındaki paylaşımların güncel olmadığı; bazı kütüphanelerin ise kamu sayfalarının yanı sıra kişi profili şeklinde de hesap oluşturdukları görülmüştür. Her sayfadaki bütün gönderilerin ve etkileşimlerin indirilmesi için Netvizz uygulaması kullanılmıştır. Netvizz uygulaması Facebook üzerinden veri toplamada kullanılan bir uygulamadır (Rieder, 2013). 1 Temmuz 2019 tarihinde gerçekleştirilen indirme işlemi sonrasında 1739 gönderiye ait zaman ve etkileşim verilerini içeren bir veri seti elde edilmiştir ${ }^{1}$. Oluşturulan veri setinden hareketle araştırmada Facebook gönderileri incelenen halk kütüphaneleri, sayfaların açılış tarihleri ve gönderi sayıları Tablo 1 'de yer almaktadir.

Tablo 1

Analizlerin gerçekleştirildiği halk kütüphaneleri ve gönderi sayıları

\begin{tabular}{lrr}
\hline Kütüphane adı & Sayfa açılış tarihi & Gönderi sayı1s1 \\
\hline Adnan Ötüken İl Halk Kütüphanesi & 2018 & 719 \\
Keçiören Cemil Meriç İlçe Halk Kütüphanesi & 2015 & 276 \\
Polatlı Halk Kütüphanesi & 2017 & 1 \\
Şuayip Çalkın Halk Kütüphanesi & 2016 & 39 \\
Pursaklar İlçe Halk Kütüphanesi & 2018 & 1 \\
Gölbaşı Hasan Celal Güzel İlçe Halk Kütüphanesi & 2014 & 176 \\
Or-An Sevgi Yıll Halk Kütüphanesi & 2016 & 15 \\
Hasanoğlan 17 Nisan Halk Kütüphanesi & 2012 & 302 \\
Sincan Evliya Çelebi Halk Kütüphanesi & 2018 & 80 \\
Sincan İlçe Halk Kütüphanesi & 2017 & 130 \\
\hline
\end{tabular}

Tablo 1'e göre Hasanoğlan 17 Nisan Halk Kütüphanesinin Facebook sayfasının 2012 yılında açıldığı anlaşılmıştır. Verilerin toplandığ 1 Temmuz 2019 tarihi itibariyle 2017 ve 2018 yılında Facebook sayfası açan iki kütüphanenin gönderi sayısı birdir. Facebook üzerinde 2016 yılında sayfa açan iki kütüphanenin gönderi sayıları 15 ve 39'dur. Bu durum söz konusu sayfaların Facebook platformunda aktif bir kullanımının olmadığına işaret etmektedir. Tablo 1'deki bulgular ayrıca en fazla gönderinin (719 gönderi) Adnan Ötüken İl Halk Kütüphanesi tarafından paylaşıldığını bu kütüphaneyi Hasanoğlan 17 Nisan Halk Kütüphanesinin (302 gönderi) ve Keçiören Cemil Meriç İlçe Halk Kütüphanesinin (276 gönderi) takip ettiğini göstermektedir.

\section{Verilerin Hazırlanması ve Analizi}

1739 gönderiden oluşan veri setinde araştırma sorularına yanıt verebilecek analizleri gerçekleştirebilmek için bazı verilerin düzenlenmesine ve dönüştürülmesine ihtiyaç duyulmuştur. Bu işlemler için KNIME yazılımı kullanılmıştır. Açık adı Konstanz Information Miner olan yazılım bir veri madenciliği yazılımıdır (Berthold ve diğerleri, 2009). Bu yazılımda ilk olarak gönderi tarihlerinin Türkiye zaman dilimine göre güncellenmesi ve saat, gün, ay, y1l gibi bölümlere ayrılması işlemleri yapılmıştır. Bununla birlikte gönderilere ilişkin etkileşim verileri ise gruplandırılarak analiz edilmiştir. Araştırmada bu süreçlerden geçirilen veriler sıklık

\footnotetext{
${ }^{1}$ Araştırma kapsamında toplanan verilerden oluşan veri seti ve analizler sırasında gerçekleştirilen metin madenciliği uygulamalarına yönelik KNIME iş akışı https://doi.org/10.17605/OSF.IO/R67AY adresinde yer almaktadır.
} 
ve yüzde tablolarıyla sunulmuştur. Söz konusu bulguların grafik gösterimleri Microsoft PowerBI yazılımıla üretilmiştir.

Oluşturulan veri setindeki gönderileri ilk olarak gözle incelenmiş ve literatürdeki benzer çalışmalarda da ele alınan beş genel konu kategorisine (etkinlik, hizmet, koleksiyon, tanıtım ve farkındalık oluşturma ve anma, kutlama ve teşekkür olmak üzere) ayrılmıştır. Sonrasında verilerde metin tabanlı bir yapıda bulunan gönderilerin analizlere hazır hale getirilmesi için de $K N I M E$ yazılımının metin işleme uzantısı ile bu uzantı kapsamındaki ön işleme, dönüştürme ve analiz operatörleri kullanılmıştır. Bir gönderinin birden çok kategoriye atanabildiği bu incelemelerde gönderilerdeki kişi etiketleri, fotoğraf, video ve duygu paylaşımları da kayıt altına alınmıştır. Gönderilerin genel konu kategorilerine ayrılmasına yönelik örnek bir gösterim Tablo 2'de verilmektedir.

Tablo 2

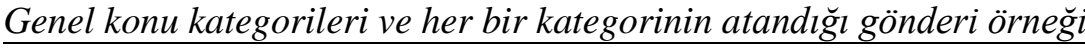

\begin{tabular}{ll}
\hline Gönderi* & Atanan kategori \\
\hline Tüm babaların babalar gününü kutlarız. & Kutlama, anma ve teşekkür \\
Yüzlerce yeni çocuk kitabı raflarda yerini aldı. & Koleksiyon \\
Yetişkinler için drama etkinliğimiz gerçekleşti. & Etkinlik \\
Çalışma salonlarımız 16 Şubat Cumartesi Saat 11:00'da açılacaktır. & Hizmet \\
Kütüphanemizden görüntüler & Tanıtım ve farkındalık oluşturma \\
\hline
\end{tabular}

* Bu sütunda verilen gönderiler kütüphanelerin Facebook sayfalarından değiștirilmeden sunulmuştur.

Tablo 2'de bir örneğinin gösterildiği etiketleme işleminin ardından gönderi metinleri üzerinde gerçekleştirilen ön işleme adımlarını şu şekilde sıralamak mümkündür:

- İlk olarak gönderiler Türkçe doğal dil işleme kütüphanesi Zemberek Tokenizer ile Türkçe için işlenebilir hale getirilmiştir.

- Her gönderideki büyük-küçük harf kullanımları standardize edilmiştir. Bu standardizasyonda her gönderi metni küçük harfe dönüştürülmüştür. Gönderilerdeki noktalama işaretleri kaldırılmıştır.

- Emojiler, hashtagler, kişi etiketleri ve URL'ler gönderilerden çıkarılmıştır.

- Türkçede anlam taşımayan kelimeler, bağlaçlar ve edatlar gibi yapılar ile gözle yapılan kontrollerde metinden çıkarılması gerekli görülen noktalama işaretleri bir dur listesi ile gönderilerden çıkarılmıştır.

- Sonrasında ise gönderilerdeki ekler Türkçe için geliştirilmiş bir gövdeleyici olan Zemberek Stemmer operatörüyle kelime köklerinden ayrılmıştır.

Tablo 2'de belirtilen beş ana kategorinin alt konuları ise n-gram tabanlı sınıflandırma uygulamaları ile analiz edilmiştir. Dokümanları ya da metinleri sınıflandırmak için kullanılan basit ve güvenilebilir bir yöntem olarak nitelendirilen n-gram, verilen bir dizilimdeki kelime ya da harflerin tekrar oranını bulmada kullanılmaktadır (Doğan, 2006, s. 14; Şeker, t.y.). Bu çalışma kapsamında gönderilerin kelime bazında bi-gram analizi yapılmış ve her bir kategorideki gönderilerde en s1k geçen kelime çiftlerinden hareketle ana kategorilerin içeriğini temsil eden alt konular saptanmıştır. Elde edilen bu bulguların sunumunda yalnızca kökleri bulunan kelimelere yönelik bulguların sunumunda okunurluğu artırmak için bu kelimelerin veri setindeki köklerine ayrılmadan önceki kullanımları tercih edilmiştir. Bunun yanı sıra n-gram analizi sonuçlarında beş kategori içeriğindeki alt konuların daha net bir şekilde saptanabilmesi için kelime çiftlerinin gönderi içerisindeki geçiş sıklığı yerine ilgili kategorideki geçiş sıklıkları verilmiştir. 


\section{Bulgular}

Araştırma kapsamında ilk olarak Ankara'daki halk kütüphanelerinin gönderilerine ilişkin tanımlayıcı istatistiklere ilişkin bulgular ele alınmıştır. Bu kapsamda ilk olarak gönderilerin Facebook'ta hangi türlerde kayıt altına alındığı incelenmiştir. İncelemeler çerçevesinde Facebook'un gönderileri tür olarak fotoğraf, bağlant1, durum güncellemesi ve video türlerinde kayıt altına aldığı görülmüştür. Bu noktada gönderiler içerik olarak birden çok tür içerse dahi (örneğin bir görsele aynı zamanda bağlantı eklenebilse dahi) tek kategoride kayıt altına alındığ anlaşılmıştır. Söz konusu kayıtlara göre gönderilerin türlere göre dağılımı Tablo 3’te sunulmuştur.

Tablo 3

Gönderilerin türlere göre dağılımı

\begin{tabular}{lrr}
\hline Tür & Sayı & Yüzde \\
\hline Fotoğraf/görsel & 1461 & 84,0 \\
Bağlantı & 42 & 2,4 \\
Durum güncellemesi & 114 & 6,6 \\
Video & 122 & 7,0 \\
\hline Toplam & 1739 & 100 \\
\hline
\end{tabular}

Bulgulara göre 1739 gönderinin \%84’ü fotoğraf ya da görsel içeren gönderidir. Gönderi türü olarak en düşük paylaşım ise 42 gönderi $(\% 2,4)$ ile bağlantı türündedir. Video paylaşımı içeren gönderi sayısı ise 122 'dir. 114 gönderi ise sadece metin tabanlı içeriğe dayanan durum güncellemesi türündedir.

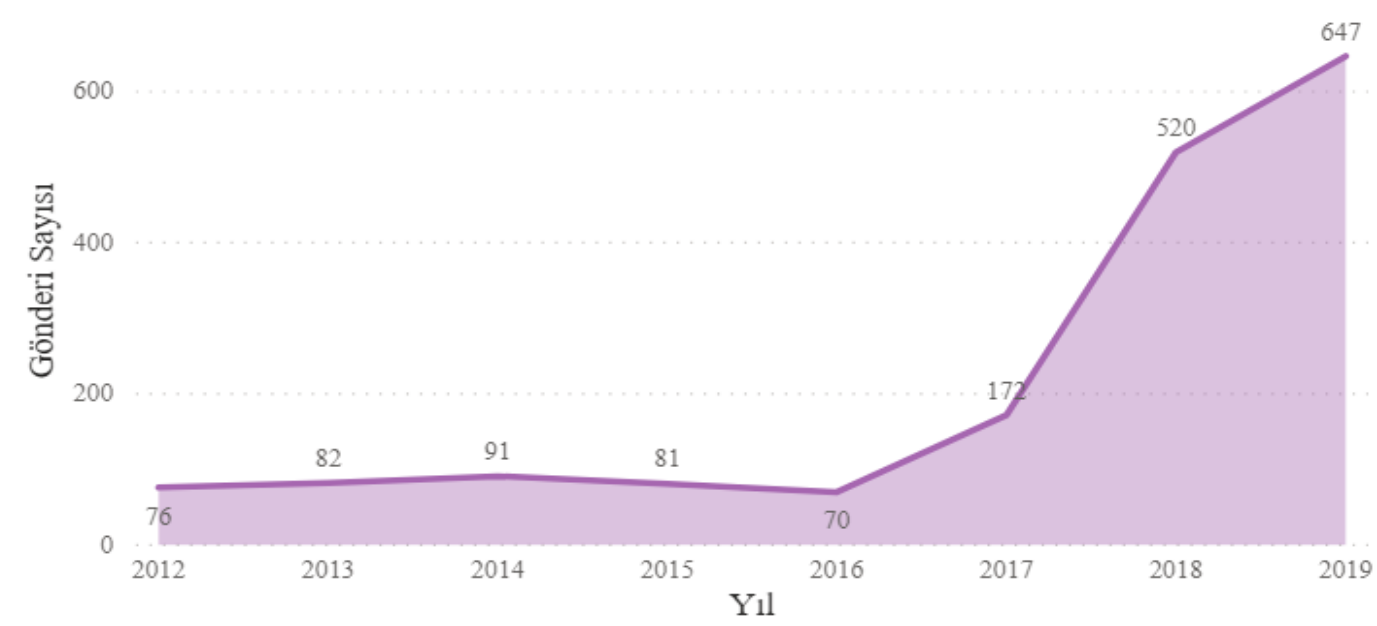

Şekil 1. Gönderilerin y1llara göre dağılımı

Şekil 1'de sunulan bilgilere göre gönderiler sayı olarak 2012 yılından 2016 yılına kadar hemen hemen aynıdır. 2017 yılından itibaren ise gönderi sayısının artış gösterdiği 2019 yılı Temmuz ayı itibariyle en yüksek sayıya ulaştığı görülmektedir. Bu sayı 2017 yılına kadarki gönderilerin toplamından daha yüksektir. Bu durumun oluşmasında Facebook platformuna yönelik farkındalığın artmasının yanı sıra kütüphane sayfalarındaki artışın da etkili olduğunu söylemek mümkündür. İncelenen halk kütüphanelerinin Facebook sayfalarındaki gönderilerin aylara göre dağılımı Şekil 2'de verilmiştir. 


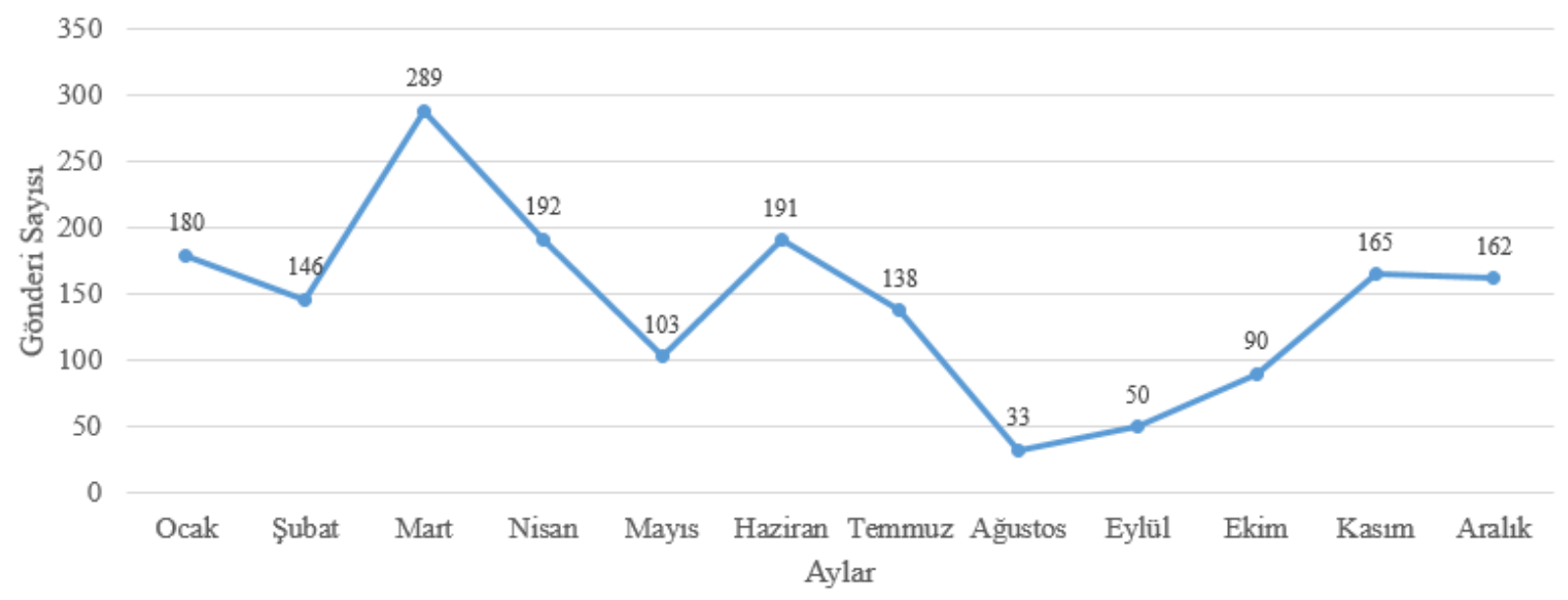

Şekil 2. Gönderilerin aylara göre dağılımı

Şekil 2'ye göre Ağustos, Eylül ve Ekim aylarındaki gönderi sayıları diğer aylara göre daha düşüktür. Gönderi sayıları Kasım ayından itibaren ise artış göstermektedir. En yüksek gönderi sayısına ise Mart ayında ulaşılmıştır.

Tablo 4

Gönderilerin günlere göre dağılımı

\begin{tabular}{lrr}
\hline Gün & Gönderi sayıs1 & Yüzde \\
\hline Pazartesi & 339 & 19 \\
Salı & 275 & 16 \\
Carşamba & 348 & 20 \\
Perşembe & 296 & 17 \\
Cuma & 270 & 15 \\
Cumartesi & 152 & 9 \\
Pazar & 59 & 4 \\
\hline
\end{tabular}

Tablo 4'te verilen bulgulara göre Pazartesi (\%19) ve Çarşamba (\%20) günleri haftanın diğer günlerine oranla daha fazla gönderi paylaşılmıştır. Ayrıca gönderi sayılarının haftanın son günlerinde düşüş göstermesi dikkat çekmektedir. $\mathrm{Bu}$ düşüşte haftanın son günlerinde gerçekleştirilen etkinlik sayısının az olması ve kütüphanelerin kapalı olması gibi nedenlerin etkisinin olabileceği düşünülmektedir. Gönderilerin saatlere göre dağılımına yönelik bulgular Şekil 3'te yer almaktadır.

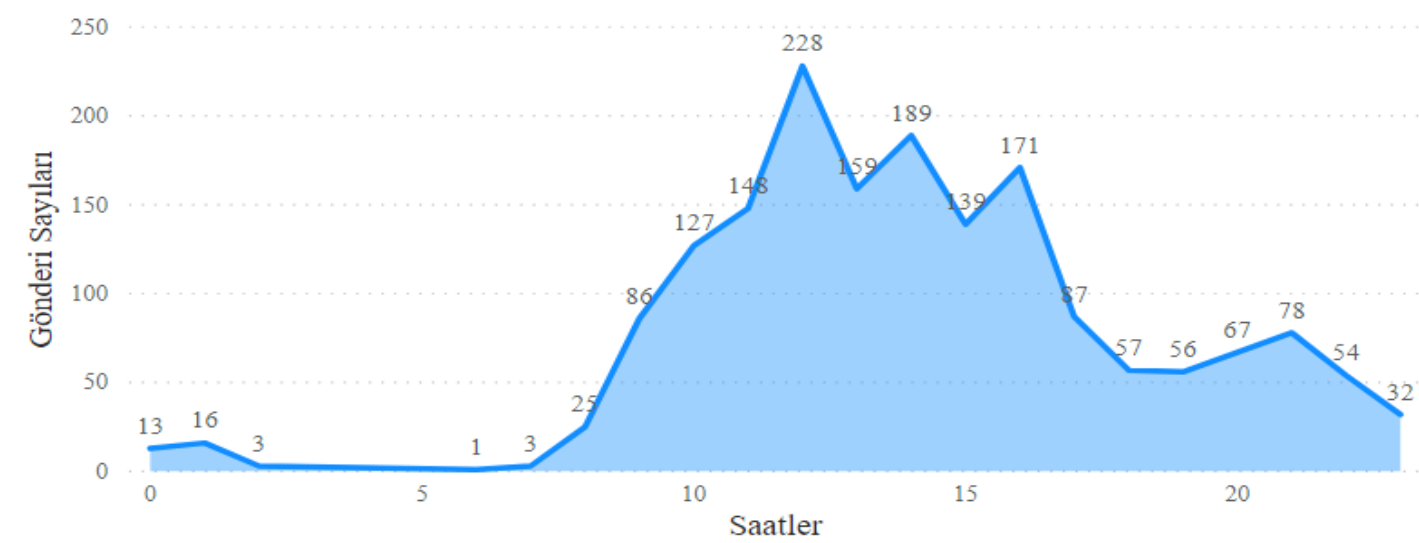

Şekil 3. Gönderilerin saatlere göre dağılımı 
Şekil 3'te verilen bulgular halk kütüphanelerinin gönderilerinin mesai saatleri içerisinde yoğunlaştı̆̆ını akşam saatlerinde ise azaldığını göstermektedir. Bulgularda en çok gönderinin paylaşıldığı saat dilimi 12.00-13.00'tür (228 gönderi). Bunu 189 gönderi ile saat 14.00-15.00 ve 171 gönderi ile 16.00-17.00 aralığındaki paylaşımlar takip etmektedir.

Tablo 5

Beğeni, yorum ve paylaşım sayılarına ilişkin bulgular

\begin{tabular}{lrrrrrr}
\hline & \multicolumn{2}{c}{ Beğeniler } & \multicolumn{2}{c}{ Paylaşımlar } & \multicolumn{2}{c}{ Yorum } \\
\cline { 2 - 6 } Etkileşim sayısı & Sayı & Yüzde & Say1 & Yüzde & Say1 & Yüzde \\
\hline 0 & 178 & 10,2 & 1139 & 65,5 & 1547 & 89 \\
$1-5$ & 665 & 38,3 & 565 & 32,5 & 177 & 10,2 \\
$6-10$ & 518 & 29,8 & 27 & 1,5 & 14 & 0,8 \\
$11-15$ & 215 & 12,4 & 5 & 0,3 & 1 & 0 \\
$16-20$ & 96 & 5,5 & 2 & 0,2 & 0 & 0 \\
$21-25$ & 25 & 1,4 & 0 & 0 & 0 & 0 \\
26 ve üzeri & 42 & 2,4 & 1 & 0 & 0 & 0 \\
\hline
\end{tabular}

Tablo 5'te sunulan bulgulara göre gönderilerin yaklaşık üçte ikisi $(\% 65,5)$ kullanıcılar tarafından hiç paylaşılmamış; \%89'u ise hiç yorum almamıştır. Bu durumun aksine beğeni almayan gönderi sayısı (178 gönderi, \%10,2) düşük bulunmuştur. Gönderilerin \%38,3'ünün aldığı beğeni sayısı bir ile beş arasındadır. Ayrıca altı ile 10 arasında beğeni alan gönderilerin oranı ise \%29,8'dir. Söz konusu bulgulardan hareketle araştırmada halk kütüphanelerinin gönderilerinin ve aldıkları beğeni, yorum ve paylaşımların yıllara göre dağılımı Şekil 4'te gösterilmiştir.

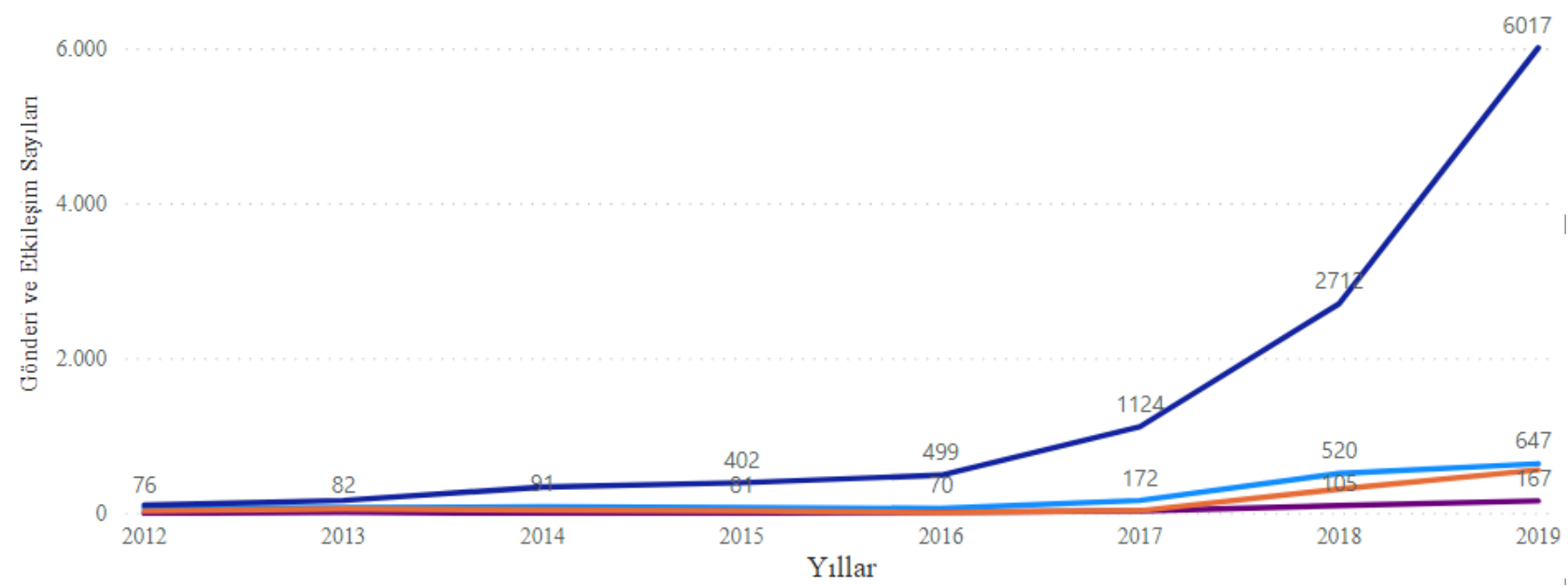

Şekil 4. Yıllara göre paylaşılan gönderi ve alınan beğeni sayıları

Şekil 4'te sunulan bulgulardan halk kütüphanelerinin gönderilerinin aldığı beğeni sayısının 2015 yılından itibaren hızlı bir şekilde yükseldiği anlaşılmaktadır. Bulgularda 2019 yılı Temmuz ayı itibariyle paylaşılan 647 gönderinin toplamda 6017 beğeni alması dikkati çekmektedir. Ayrıca yıllar bazında kütüphane sayfaların ve gönderi sayılarının artmasıyla birlikte beğeni sayılarının da arttığı görülmektedir. Ancak bu artışın gönderi sayısının çok daha üstünde olduğunu söylemek mümkündür. Diğer taraftan yorum ve paylaşım sayılarının gönderi sayısının altında seyrettiği görülürken paylaşım sayısının 2017 yılından itibaren yorum sayısına 
göre daha yüksek sayılara ulaştığı dikkat çekmektedir. Gönderilerin aldıkları beğenilerin aylara göre dağılımını gösteren bulgular Şekil 5’te verilmiştir.

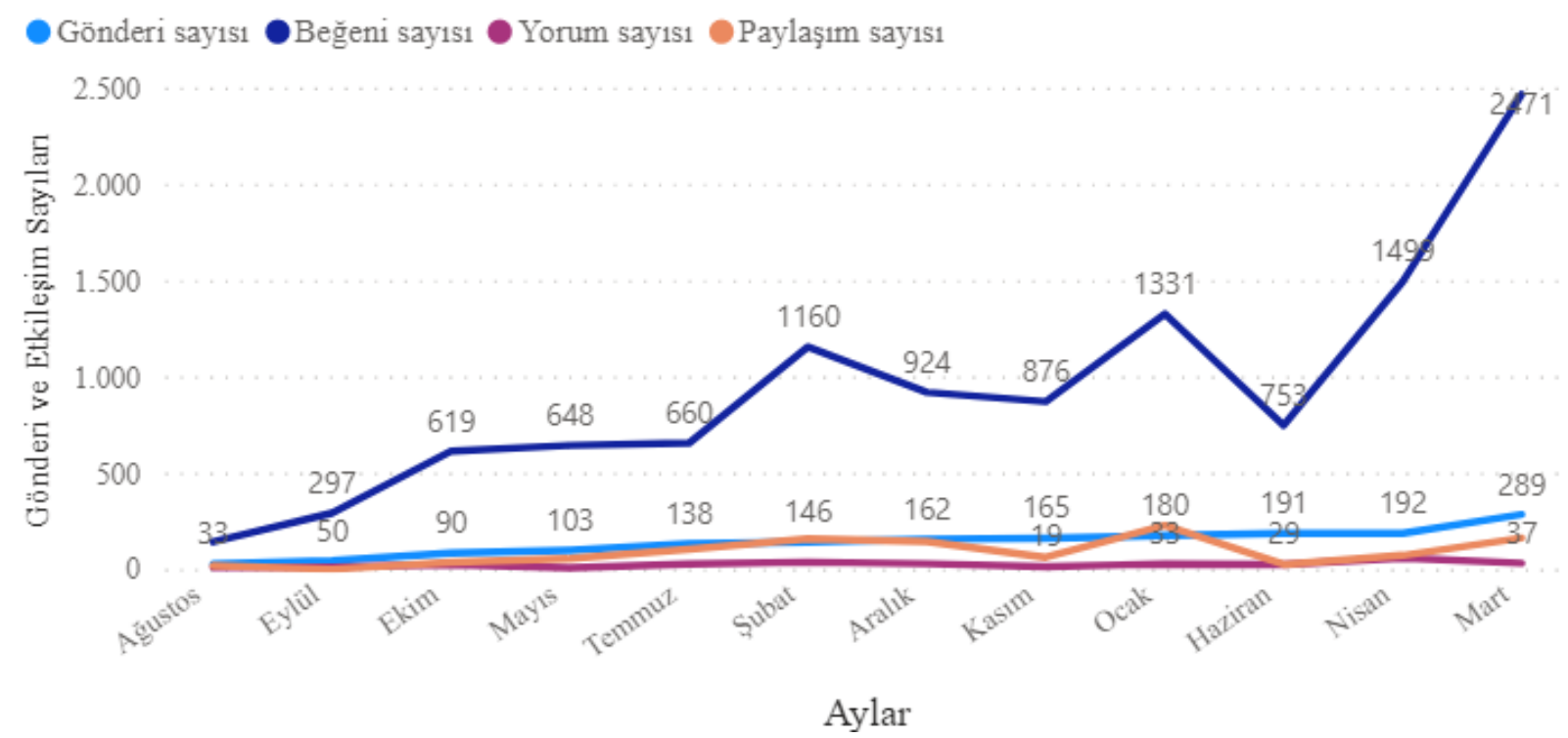

Şekil 5. Aylara göre paylaşılan gönderi ve alınan beğeni, yorum ve paylaşım sayıları

Şekil 5'e göre gönderi sayısının en yüksek olduğu ay olan Mart ayı en yüksek beğeni sayısına ulaşılan ay olarak da öne çıkmaktadır. Nisan ayında paylaşılan 192 gönderi 1499 beğeni almıştır. Hemen hemen Nisan ayıyla aynı sayıda gönderinin paylaşıldığı Haziran ayında alınan beğeni sayısının düşük olduğu dikkati çekmektedir. Bunun yanı sıra Haziran ayına göre daha az gönderinin paylaşıldığ 1 Ocak (180 gönderi, 1331 beğeni), Kasım (165 gönderi, 876 beğeni), Aralık (162 gönderi, 924 beğeni) ve Şubat (146 gönderi, 1160 beğeni) aylarındaki gönderilerin aldığı beğeni sayısı Haziran ayındaki gönderilerin (191 gönderi, 753 beğeni) aldığ1 beğenilerin sayısından daha yüksektir. Yorum ve paylaşım sayılarının genellikle düşük sayıda olduğu gözlenen bulgularda en yüksek paylaşım sayısına Ocak ayındaki gönderilerde ulaşılmıştır. Gönderilerin haftanın günlerine göre aldıkları beğeni, yorum ve paylaşım sayıları Şekil 6'da sunulmuştur.

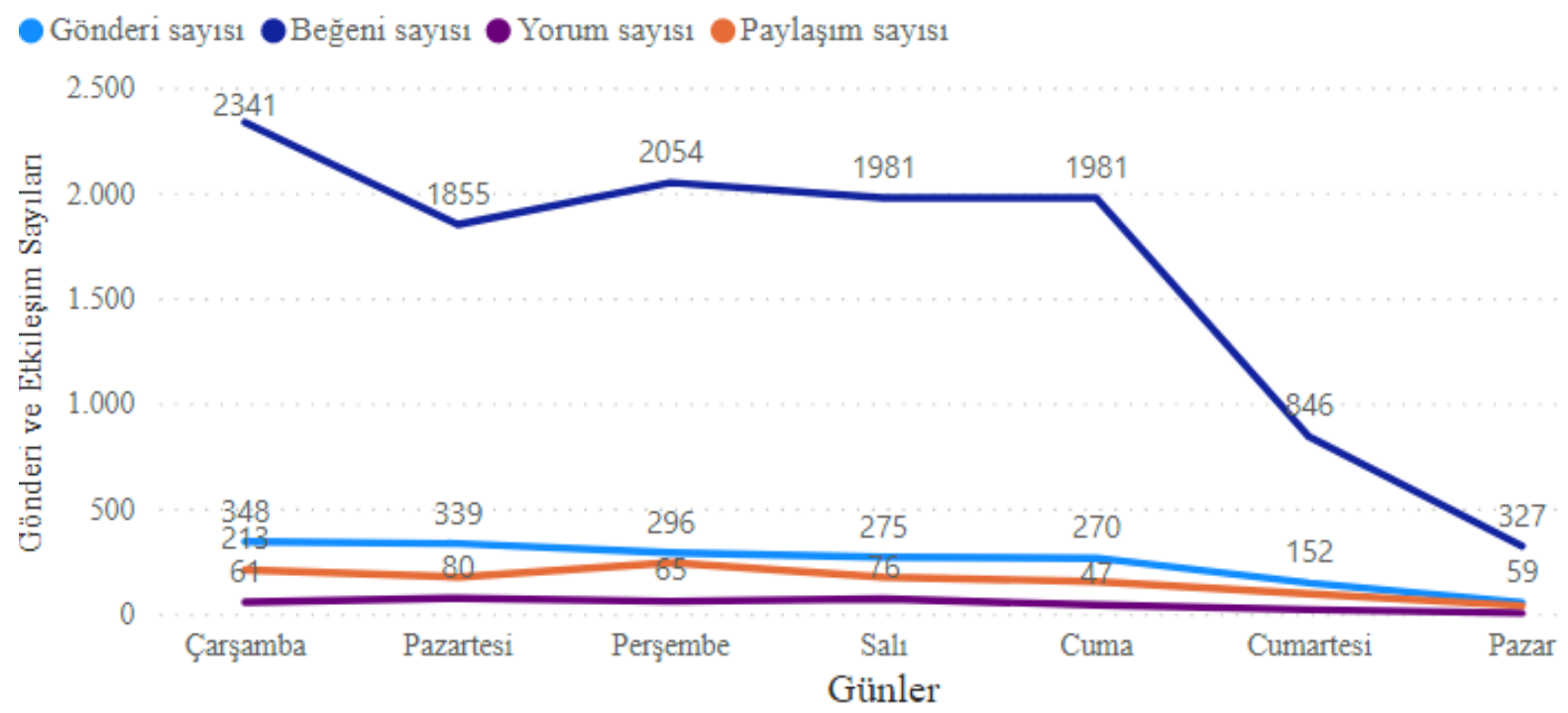

Şekil 6. Günlere göre paylaşılan gönderi ve alınan beğeni, yorum ve paylaşım sayıları 
Bulgulara göre en fazla gönderinin paylaşıldığı gün olan Çarşamba günü en fazla beğeninin alındığı (2341 beğeni) anlaşılmaktadır. En fazla gönderiye sahip ikinci gün olan Pazartesi günü paylaşılan gönderiler 1855 beğeni almıştır. Perşembe günü paylaşılan 296 gönderi ise toplamda 2054 beğeni almıştır. Bulgularda haftanın son günlerindeki gönderilerin daha az beğeni aldığı ve beğeni sayılarının Çarşamba ve Perşembe günlerindeki gönderilerde daha yüksek olduğu ortaya çıkmaktadır. Söz konusu bulgular yorum ve paylaşımlar açısından değerlendirildiğinde ise Pazartesi ve Salı günlerinde yapılan gönderilerin yorum sayılarının (sırasıyla 80 ve 76) diğer günlere göre yüksek olduğu görülmektedir. Genel olarak etkileşim açısından yorumlara göre daha fazla tercih edilen paylaşımların ise en yüksek sayıya ulaştığı gün Perşembe'dir. Gönderilerin saat olarak paylaşım zamanları bazında aldıkları beğeniler Şekil 7'de yer almaktadır.

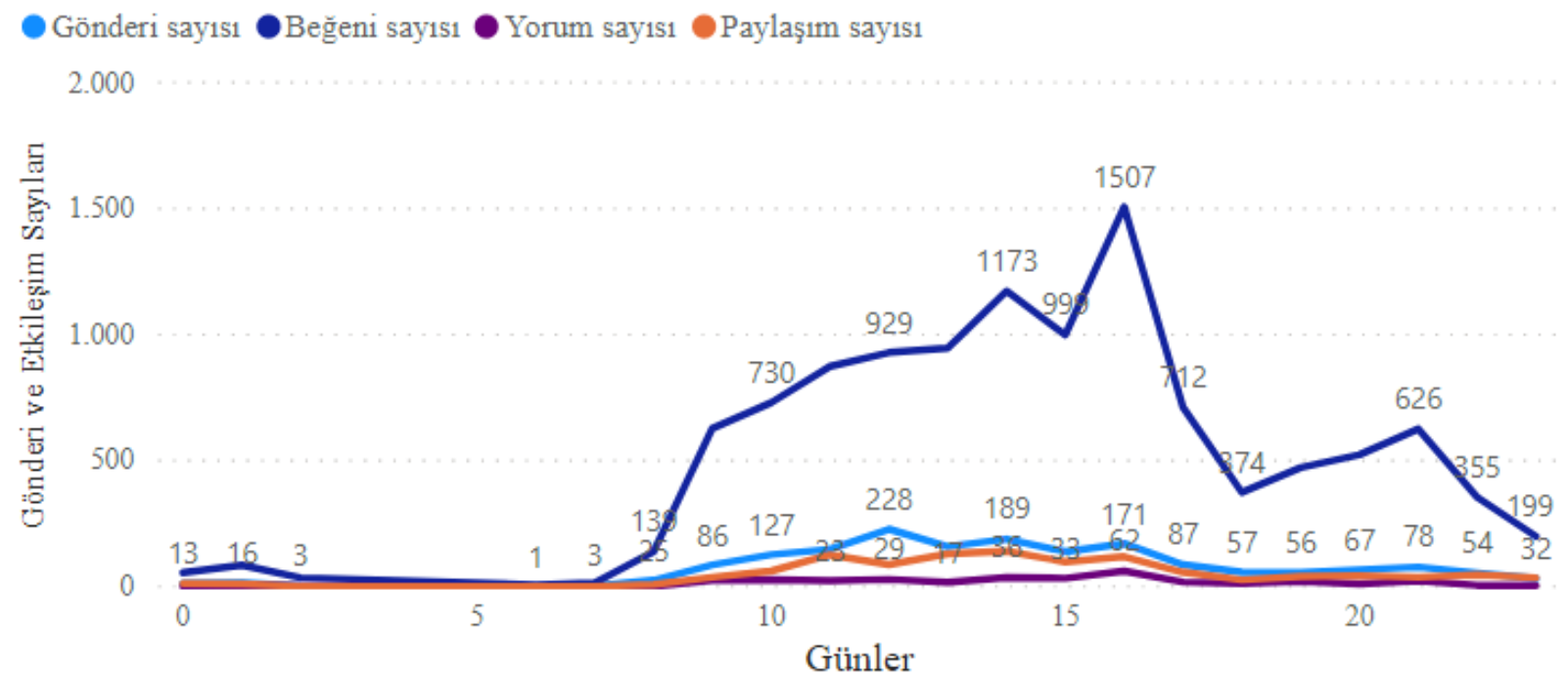

Şekil 7. Saatlere göre paylaşılan gönderi ve alınan beğeni, yorum ve paylaşım sayıları

Şekil 7'ye göre mesai saatleri içerisindeki paylaşımların beğeni sayıları yüksektir. Bu kapsamda 171 gönderinin paylaşıldığı 16.00-17.00 saat aralığındaki gönderiler en yüksek beğeni sayısına (1507 beğeni) sahiptir. En fazla gönderinin paylaşıldığı saat aralığındaki (228 gönderi, 12.00-13.00 aralığı) gönderiler toplamda 929 beğeni almıştır. Akşam saatlerindeki gönderilerde ise saat 20.00-21.00 aralığındaki 67 gönderi 523 beğeni alırken, 21.00-22.00 aralığında paylaşılan 78 gönderi 626 beğeni almıştır. Sabah saatlerindeki gönderilerde ise saat 10.00-11.00 arasındaki 127 gönderi 730 beğeni almıştır. Bunu 628 beğeninin alındığ $09.00-$ 10.00 aralığındaki gönderiler takip etmiştir, 08.00-09.00 aralığındaki 25 gönderi 135 beğeni almıştır. Gönderilerin saatlere göre dağılımında aldıkları yorum ve paylaşım sayılarının da önceki bulgularla benzerlik gösterdiği görülmektedir. Özellikle saat 11.00'dan itibaren paylaşım sayısının yorum sayısına göre daha yüksek olduğu Şekil 7'den anlaşılmaktadır.

Araştırmanın ikinci bölümünde kütüphanelerin gönderilerinin içerikleri analiz edilmiştir. Buna göre 1739 gönderinin 254'ünün bir metin içeriğinin olmadığı tespit edilmiştir. Gönderilerin 76'sı fotoğraf paylaşımı (profil veya kapak fotoğrafı güncellemesi ya da fotoğraf albümü ekleme), 37'si bağlantı ve altısı ise video paylaşımı bildirimi niteliğindedir. Buna ek olarak veri setindeki iki gönderinin yalnızca kişi etiketi, üç gönderinin konum bildirimi, bir gönderinin ise yalnızca duygu paylaşımı içerdiği anlaşılmıştır. Bu gönderiler konu 
kategorizasyonu için bir anlam taşımadığı için araştırma kapsamı dışında tutulmuştur. Söz konusu incelemeler sonucunda konu kategorizasyonu 1360 gönderi üzerinde yapılmıştır.

Gönderilerin içeriklerine yönelik analizlerde ilk olarak gözle yapılan kategorizasyon çalışmasına ilişkin bulgulara ulaşılmıştır. Bir gönderinin birden çok kategoride etiketlenebildiği bu analizler çerçevesinde elde edilen bulgular Tablo 6' da sunulmuştur.

Tablo 6

Gönderilerin kategorilere göre dă̆llımı ve veri setindeki gönderi sayısına (1739 gönderi) göre oranları

\begin{tabular}{lrr}
\hline Gün & Gönderi sayısı & Yüzde \\
\hline Etkinlik & 743 & 42,7 \\
Tanıtım ve farkındalık oluşturma & 358 & 20,6 \\
Kutlama, anma ve teşekkür & 351 & 20,2 \\
Hizmet & 155 & 8,9 \\
Koleksiyon & 50 & 2,9 \\
\hline
\end{tabular}

Tablo 6'dan da anlaşılacağı üzere metin tabanlı içeriğe sahip olan 1360 gönderi toplamda 1657 etiketle tanımlanmıştır. Buna göre gönderilerin \%44,8'i kütüphanelerin düzenlediği ya da düzenleyecek oldukları etkinliklere yöneliktir. Gönderilerin yaklaşık beşte biri (358 gönderi, \%20,6) pazarlama veya farkındalık oluşturma kategorisindedir. Bunu \%20,2'lik oranla (351 gönderi) kutlama, anma ve teşekkür mesajları takip etmektedir. Veri setindeki 155 gönderi $(\% 8,9)$ hizmetler kategorisinde değerlendirilmiştir. 50 gönderi $(\% 2,9)$ ise koleksiyon kategorisinde yer almıştır.

Belirlenen beş kategoriye (etkinlik, pazarlama ve promosyon, kutlama, anma ve teşekkür, hizmet ve koleksiyon) yönelik alt kategorilerin tespit edilmesi için her kategorideki gönderilere ilişkin bi-gramlar oluşturulmuştur. Bu kapsamda ilk olarak etkinlik kategorisindeki 743 gönderide çoğunlukla geçen kelime çiftleri belirlenmiştir (Tablo 7).

Tablo 7

Etkinlik kategorisindeki gönderilerde çoğunlukla geçen kelime çiftleri

\begin{tabular}{lllr}
\hline Kelime çiftleri & Gönderi sayısı & Kelime çiftleri & Gönderi sayısı \\
\hline teşekkür ederiz & 77 & hep birlikte & 22 \\
devam ediyor & 62 & etkinliklere katılım & 22 \\
masal saati & 55 & kütüphanede yarıyıl & 22 \\
kütüphane oryantasyonu & 43 & kütüphanemizi tanıyoruz & 21 \\
öğrenci kütüphane & 42 & çok teşekkür & 21 \\
kitap okuma & 40 & katılı̈ ücret & 21 \\
sinıfı öğrencileri & 38 & çocuk kitapları & 21 \\
kütüphane haftası & 37 & 55 kütüphane & 20 \\
kütüphane ziyareti & 31 & aşağı bağlantı & 19 \\
gerçekleştiriyoruz kütüphane & 30 & yap kütüphane & 19 \\
etkinlik gerçekleştiriyoruz & 29 & tüm hızıyla & 19 \\
kütüphane kütüphanedeyim & 27 & ayrıntı bilgi & 18 \\
yarıyıl programı & 25 & bilgi alabilirsiniz & 18 \\
örgü atölyesi & 24 & hizıyla devam & 18 \\
masal okuma & 24 & kariyer günü & 18 \\
web sitemizde & 23 & okuma saati & 17 \\
hakkında bilgi & 23 & dinleyelim beraber & 17 \\
saat 1400 & 23 & kütüphane tanıtımı & 17 \\
masal dinletisi & 23 & Mart 2019 & 17 \\
masal anlatımı & 23 & kitapları haftası & 17 \\
\hline
\end{tabular}


Tablo 7'de verilen bulgulara göre etkinlik kategorisindeki gönderilerde en çok geçen kelime çifti 77 gönderide yer alan "teşekkür ederiz" ifadesidir. Bu ifadeyi etkinlik sırasında paylaşım yapıldığını gösteren "devam ediyor" (62 gönderi) ifadesi takip etmektedir. Etkinlik içeriklerine yönelik ifadeler incelendiğinde ise 55 gönderide geçen "masal saati" ile 43 gönderide yer alan "kütüphane oryantasyonu” ifadeleri dikkati çekmektedir. Ayrıca, Tablo 7'de verilen kelime çiftlerinden aynı tema kapsamındaki gönderilerin paylaşıldığı anlaşılmaktadır. Nitekim, "kitap okuma" (40 gönderi), "masal okuma" (24 gönderi), "masal dinletisi" (23 gönderi), "masal anlatımı" (23 gönderi) "dinleyelim beraber” (17 gönderi) gibi ifadeler kütüphanelerin kitap ve masal odaklı etkinlikler düzenlediğini göstermektedir. Diğer yandan "sınıfi öğrencileri” (38 gönderi), "kütüphane ziyareti” (31 gönderi), "kütüphanemizi tanıyoruz" (21 gönderi), "kütüphane tanıtımı” (17 gönderi) gibi kelime çiftleri kütüphane tanıtımına ilişkin etkinliklerin düzenlendiğini yansıtmaktadır. İlgili bulgularda ayrıca belirli gün ve haftalara veya dönemlere yönelik etkinliklerin de gönderilerde ele alındığı ortaya çıkmaktadır. Bu kapsamda gönderilerde "kütüphane haftası" (37 gönderi), "55 kütüphane" (20 gönderi), "çocuk kitapları" (21 gönderi), "kütüphanede yarıyıl” (22 gönderi), yarıyıl programı (25 gönderi), "Mart 2019” (17 gönderi), "kitapları haftası" (17 gönderi) kelimeleri öne çıkmaktadır. Etkinlik içerikleri bağlamında son olarak "örgü atölyesi” (24 gönderi) ve "kariyer günü” (18 gönderi) ifadeleri ise kütüphanelerin farklı kullanıcı gruplarına yönelik etkinlikler düzenlediğini de göstermektedir. Ayrıca kütüphanelerin düzenlenecek etkinliklere yönelik paylaşımlarının yanı sıra etkinlik sırasında da gönderi paylaştıklarını söylemek mümkündür. Bu çerçevede "devam ediyor”, "tüm hızıyla" "hızıyla devam" gibi kelime gruplarının gönderilerde yer aldığı görülmektedir. Son olarak "saat 1400", "katılım ücretsiz", "aşağıdaki bağlantı" gibi kelimelerden düzenlenen etkinlikle ilgili bilgilendirmelerin olduğu anlaşılmaktadır.

Tablo 8

Kutlama, anma ve teşekkür kategorisindeki gönderilerde çoğunlukla geçen kelime çiftleri

\begin{tabular}{lllr}
\hline Kelime çiftleri & Gönderi sayısı & Kelime çiftleri & Gönderi sayısı \\
\hline teşekkür ediyoruz & 60 & saygıyla anıyoruz & 11 \\
kutlu olsun & 50 & dünya çocuk & 11 \\
sevgili okuyucularımız & 27 & devam ediyor & 11 \\
Mustafa Kemal & 27 & 55 kütüphane & 10 \\
Kemal Atatürk & 26 & minnetle anıyoruz & 10 \\
sevgili okur & 25 & okur var & 10 \\
var olun & 25 & kütüphane oryantasyonu & 10 \\
kütüphane haftas & 23 & kütüphane ziyareti & 10 \\
günü kutlu & 21 & kütüphane personeli & 9 \\
bayram kutlu & 16 & Atatürk'ü anma & 9 \\
çocuk kitapları & 15 & İstiklal marşı & 9 \\
Gazi Mustafa & 14 & silah arkadaşları & 9 \\
Mehmet Akif & 13 & Cumhuriyet Bayramı & 9 \\
Akif Ersoy & 13 & herkese teşekkür & 9 \\
kitap okuma & 13 & emeği geçen & 9 \\
kütüphane kütüphanedeyim & 12 & masal saati & 9 \\
kitapları haftası & 12 & masal okuma & 9 \\
çok teşekkür & 12 & tebrik ederiz & 8 \\
23 Nisan & 11 & 19 Mayıs & 8 \\
hafta kutlu & 11 & Gençlik Spor & 8 \\
\hline
\end{tabular}

Tablo 8'deki bulgular incelendiğinde kutlama, anma ve teşekkür kategorisindeki gönderilerde en yoğun olarak geçen kelime çiftleri "teşekkür ediyoruz" (60 gönderi) ve "kutlu olsun” (50 gönderi) ifadeleridir. Bu kategoride yer alan "sevgili okuyucularımı”" (27 gönderi), 
"sevgili okur" (25 gönderi) şeklinde kelime grupları ise kütüphanelerin gönderilerde hitap içeren ifadeler kullandıklarını göstermektedir. Gönderi içeriklerinde "Mustafa Kemal" (27 gönderi) ve "Kemal Atatürk" (26 gönderi) kelimeleri öne çıkmaktadır. Bununla birlikte "Gazi Mustafa", "Mehmet Akif”, “Akif Ersoy”, “23 Nisan”, “Atatürk'ü anma”, “İstiklal Marş1" "Cumhuriyet Bayramı”, “19 Mayıs”, “Gençlik Spor”, "silah arkadaşları”, "saygıyla anıyoruz”, "minnetle anıyoruz" gibi kelime grupları bu kategorideki gönderilerin yoğunlukla ulusal bayram ve anma günlerine ilişkin olduğunu ortaya çıkarmaktadır. Ek olarak 16 gönderide yer alan "bayramı kutlu" ifadesinden bayram kutlamaya yönelik içeriklerin oluşturulduğu görülmektedir. Bunun dışında 23 gönderide geçen "kütüphane haftası", 21 gönderideki "günü kutlu” 12 gönderideki "kitapları haftası", 11 gönderide geçen "dünya çocuk" ve 10 gönderideki "55 kütüphane" ifadelerinden belirli gün ve haftalara yönelik kutlama mesajlarının da bu kategoride yer aldığı çıkarımını yapmak mümkündür. $\mathrm{Bu}$ kategoride ayrıca etkinlik kategorisinde de (bkz. Tablo 7) yer alan "kitap okuma" (13 gönderi), "devam ediyor" (11 gönderi), "kütüphane oryantasyonu”, (10 gönderi), "kütüphane ziyareti” (10 gönderi), "masal saati” (9 gönderi), "masal okuma" (9 gönderi) gibi kelime çiftlerinden bulunmasının söz konusu gönderilerde yer alan teşekkür mesajlarından kaynaklandığı düşünülmektedir. Nitekim dokuzar gönderide yer alan "emeği geçen" ve "herkese teşekkür" ifadeleri bu durumu doğrular niteliktedir.

Tablo 9

Koleksiyon kategorisindeki gönderilerde çoğunlukla geçen kelime çiftleri

\begin{tabular}{lrlr}
\hline Kelime çiftleri & Gönderi sayısı & Kelime çiftleri & Gönderi sayısı \\
\hline göz attınız mı & 14 & sitemizde yayınlanan & 4 \\
web sitemizde & 8 & kitaplara göz & 4 \\
ayı enlerine & 6 & istediğiniz kitap & 4 \\
enlerine göz & 6 & işlem gerçek & 4 \\
attınız mı en & 6 & seçtiğimiz haftanın & 4 \\
en çok & 6 & haftanın kitapları & 4 \\
çok okunan & 6 & kitapları ilgili & 4 \\
okunan en & 6 & ilgili detaylı & 4 \\
okunanlar listesi & 6 & detaylı bilgi & 4 \\
listemizde listede & 6 & yeni kitaplar & 4 \\
listede kendini & 6 & kitap numarası & 4 \\
kendini görebilen & 6 & numarası birlikte & 4 \\
görebilen var mı & 6 & 15 günlük & 4 \\
var mı enlerimiz & 6 & günlük ödünç & 4 \\
enlerimiz aylı & 6 & ödünç verme & 4 \\
\hline
\end{tabular}

50 gönderi ile en az sayıda gönderinin yer aldı ğ 1 koleksiyon kategorisinde yer alan kelime çiftlerinden "göz attınız mı" ifadesi 14 gönderide yer alan ve bu kategoride en fazla geçen kelime çifti olmuştur. Bunu 8 gönderide geçen "web sitemizde" ifadesi takip etmiştir. Tablo 9'da yer alan ve altışar gönderide geçen kelime çiftleri ise "ayı enlerine”, “enlerine göz”, “en çok", "çok okunanlar", "okunanlar listesi” gibi ifadelerdir. Bu noktada koleksiyon kategorisindeki gönderilerde kütüphanelerin en çok okunan kitapları paylaştıkları ve Facebook gönderileri aracılığıyla kullanıcıları kütüphane web sitelerine yönlendirdikleri anlaşılmaktadır. Ayrıca "listede kendini", "kendini görebilen", "görebilen var mı" ifadeleri ise kütüphanelerin kullanıcılarla etkileşim kurmak için soru kalıplarını kullandıkları şeklinde yorumlanabilir. Tablo 9'da dörder gönderide yer aldığı belirtilen "seçtiğimiz haftanın", "haftanın kitapları", "yeni kitaplar" ifadeler kütüphanelerin haftalık olarak kitap önerilerinde bulunduklarını ve yeni 
gelen kitaplarla ilgili olarak az sayıda da olsa gönderi paylaştıklarını göstermektedir. Bu kategorideki "ilgili detaylı", "kitap numarası", "numarası birlikte”, "15 günlük", "günlük ödünç", "ödünç verme" kelimeleri de kütüphanelerin bu kitaplarla ilgili bilgileri ve ödünç verme hizmetlerine yönelik bilgilendirmelerde bulunduklarını yansıtmaktadır. Tablo 9'daki bulgular gönderi içeriklerinin genellikle kitap türündeki bilgi kaynaklarına ilişkin bilgilerin gönderilerde paylaşıldığını göstermesi açısından dikkat çekicidir.

Tablo 10

Hizmet kategorisindeki gönderilerde çoğunlukla geçen kelime çiftleri

\begin{tabular}{lrlr}
\hline Kelime çiftleri & Gönderi sayıs1 & Kelime çiftleri & Gönderi sayısı \\
\hline çalışma salonlarımız & 20 & okuyucu salonlarımız & 6 \\
hizmet vermeye & 13 & kütüphane çalışma & 6 \\
hizmet sunmaya & 13 & Cumartesi günü & 6 \\
günü kapalı & 11 & kütüphane personeli & 6 \\
web sitemizde & 10 & hizmetinize açık & 6 \\
ödünç verme & 10 & gezici kütüphane & 6 \\
sosyal medya & 9 & kütüphane haftası & 6 \\
devam ediyor & 9 & teşekkür ederiz & 6 \\
kapalı olacaktır & 9 & okuyucularımıza daha & 5 \\
Pazartesi günü & 7 & daha hızlı & 5 \\
vermeye devam & 7 & hızlı etkin & 5 \\
tarih aralığında & 7 & etkin hizmet & 5 \\
kütüphanemiz hizmet & 7 & sunabilmek gelen & 5 \\
millet kıraathane & 7 & gelen talepleri & 5 \\
değerli kullanıcılarımız & 7 & talepleri görüşleri & 5 \\
değerlendirme amacıyla & 6 & görüşleri daha & 5 \\
değerli okuyucularımız & 6 & hızlı değerlendirmek & 5 \\
çalışmaya devam & 6 & amaciyla Whatsapp & 5 \\
\hline
\end{tabular}

Koleksiyon kategorisinin ardından en az gönderinin etiketlendiği bir diğer kategori olan hizmet kategorisinde en fazla geçen kelime çifti "çalışma salonlarımız" (20 gönderi) ifadesidir. Bunu 13'er gönderide geçen "hizmet vermeye" ve "hizmet sunmaya" kelime grupları takip etmektedir. Ayrıca "günü kapalı" ifadesi 11 gönderide geçmektedir. Bu doğrultuda Tablo 10'da yer alan "devam ediyor", "kapalı olacaktır", "Pazartesi günü", "vermeye devam", "tarih aralığında", "kütüphanemiz hizmet", "okuyucu salonlarımız", "kütüphane çalışma", "çalışmaya devam", "Cumartesi günü", "hizmetinize açlk" şeklindeki kelime çiftlerinden kütüphanelerin işletimsel boyutta (açık ve kapalı olma durumları gibi) paylaşımda bulundukları anlaşılmaktadır. Hizmet kategorisindeki gönderilerde "web sitemizde" ve "ödünç verme" kelime çiftleri (10'ar gönderi) öne çıkmaktadır. Bu kategorideki gönderilerde ödünç verme ve gezici kütüphane hizmetleri ile sosyal medya etkileşimine yönelik paylaşımlara yer verilmektedir. Bu tablodaki bulgular genel olarak değerlendirildiğinde işletimsel süreçlere yönelik bilgi içeren kelime gruplarının diğer hizmetlere yönelik kelime gruplarından daha fazla olduğunu söylemek mümkündür.

Tanıtım ve farkındalık kategorisinde etiketlenen gönderilerde geçen kelime çiftlerinin sıklık bilgilerinin paylaşıldığı Tablo 11'de en yoğun kullanılan kelime çiftleri "sevgili okuyucularımı" (36 gönderi), ile "sevgili okurlarımız" ve "var olun" (31 gönderi) ifadeleridir. Bunu 20 gönderide geçen "kitap okuma" ile 18 gönderide geçen "web sitemizde" kelimeleridir. Kelime çiftleri incelendiğinde bu kategoride de kütüphanelerin "sevgili okuyucularımız", "sevgili okurlarımız", "günaydın değerli" gibi kelime çiftleriyle karşılama mesajlarına gönderilerde yer verdikleri görülmektedir. Diğer taraftan kütüphanelerin en çok okuyan 
kullanıcılara yönelik paylaşımlarının da bu kategoride yer aldığı anlaşılmaktadır. Bu noktada “en çok” (13 gönderi), "okurlarımız var” (10 gönderi), “çok okuyanlar” (7 gönderi) "okuyanlar listesinde" (6 gönderi), kelime çiftleri dikkati çekmektedir. Konuyla ilgili olarak "okumaya davet” ve "kitap okuma”, "kitap kazanın”, "bugün oku” kelimeleri bu kategorideki gönderilerde okumaya teşvik etmeye yönelik ifadelerin kullanıldığını göstermiştir. Bunun yanı sıra 10 gönderide geçen, "sosyal medya" ile sekizer gönderide geçen "takip edebilirsiniz" ve "medya hesaplarımızı" gibi ifadelerle kütüphanelerin bir takipçi kitlesi oluşturmaya (community building), yedişer gönderide geçen "çııın gelin", "gelin kütüphanemize" ile beş gönderide geçen "kütüphaneye gelin" şeklindeki ifadelerle kütüphane kullanımını teşvik etmeye yönelik içerikler oluşturdukları ortaya çıkmaktadır. Tablo 11'de yer alan ve 7 gönderide yer alan "meydan okumaya" ifadesi kütüphanelerin kullanıcı etkileşimi için sosyal medya kampanyalarını kullandıklarını gösteren bir bulgudur. Bu tablodaki kelime çiftlerinin bir bölümü diğer tablolarda yer alan kelime çiftlerinin bir bölümüyle örtüşmektedir. Bu durumun gönderilerin birden çok kategoride etiketlenmesinden kaynaklandığını söylemek mümkündür.

Tablo 11

Tanıtım ve farkındalık oluşturma kategorisindeki gönderilerde çoğunlukla geçen kelime çiftleri

\begin{tabular}{lrlr}
\hline Kelime çiftleri & Gönderi sayısı & Kelime çiftleri & Gönderi sayısı \\
\hline sevgili okuyucularımız & 36 & kütüphane hafta & 7 \\
sevgili okurlarımız & 31 & yer alıyor & 7 \\
var olun & 31 & meydan okumaya & 7 \\
kitap okuma & 20 & hakkında bilgi & 7 \\
web sitemizde & 18 & hiçbir şey & 7 \\
en çok & 13 & günaydın değerli & 7 \\
her şey & 13 & çıkın gelin & 7 \\
bilgi almak & 12 & gelin kütüphanemize & 7 \\
aşağıdaki bağlantıdan & 12 & enlerimize göz & 6 \\
göz atabilirsiniz & 10 & okuyanlar listesinde & 6 \\
sosyal medya & 10 & kütüphane hizmet & 6 \\
devam ediyor & 10 & bağlantıyı tıklayın & 6 \\
okurlarımız var & 10 & bugün oku & 6 \\
bağlantıdan ulaşabilir & 9 & okumaya davet & 6 \\
ayı enlerine & 8 & mutlu olun & 6 \\
takip edebilirsiniz & 8 & güncel haber & 5 \\
medya hesaplarımızı & haber duyuru & 5 \\
teşekkür ederiz & 8 & kitap kazanın & 5 \\
çok okuyanlar & 7 & kütüphaneye gelin & 5 \\
sitemizde yayınlandı & çocuk kitapları & 5 \\
\hline
\end{tabular}

\section{Sonuç ve Öneriler}

Sosyal medya etkileşimindeki artış bu ortamın kurumsal amaçlara yönelik olarak da kullanılmasını sağlamıştır. Birçok kurum markalaşma, ürün ve hizmet sunma, pazarlama ve gelişmeleri izleme gibi amaçlarla sosyal medya platformlarında kullanıcı hesabı veya kamu sayfalarını oluşturmuştur. Kurumların sosyal medya platformlarını kullanım şekilleri ve kullanmayı tercih ettikleri sosyal medya platformları sektörlere göre de farklılık gösterebilmektedir. Örneğin bir haber ajansı Whatsapp platformunu kullanıcılardan gelen haber bildirimlerini içerik olarak değerlendirmek için kullanabilirken, ürün ya da hizmet sunan bir şirket Instagram, Facebook ya da Twitter gibi araçları pazarlama ve kullanıcı etkileşimi için kullanabilmektedir. Sosyal medyayı hemen her kurum için hatta kurum içi kullanım da dahil olmak üzere önemli bir etkileşim kanalı olarak da değerlendirmek mümkündür. Kütüphaneler 
de bilgi hizmetlerinin pazarlanması ve kullanıcı etkileşimi gibi amaçlarla sosyal medyayı kullanmaktadır. Bunun yanı sıra birçok kurumda olduğu gibi kütüphaneler de sosyal medyada ürettikleri içerikleri analiz ederek kullanıı beklentilerini karşılamakta, karar alma süreçlerini desteklemekte ve sosyal medya platformların etkin bir şekilde kullanma gibi konularda değerlendirmeler yapabilmektedir. $\mathrm{Bu}$ noktada özellikle sosyal medya platformlarının geliştirilen içeriği işlenebilir ve analiz edilebilir bir formatta sunmaları da bu değerlendirmelerin yapılmasında etkili olmaktadır. Konuyla ilgili literatür incelendiğginde Facebook ve Twitter gibi platformlar başta olmak üzere kütüphanelerin bu platformlarda ürettikleri içeriklere birçok analizin yapıldığı görülmektedir. Bu çalışmada da Ankara'daki halk kütüphanelerinin Facebook platformunu kullanımlarının analiz edilmesi amaçlanmıştır. Bu çerçevede resmî olarak halk kütüphaneleri tarafından kullanılan 10 sayfadaki 1739 gönderi ve bu gönderilere ilişkin etkileşim verileri analiz edilmişsir.

Çalışmada incelenen halk kütüphanelerinin gönderilerinde çoğunlukla metinsel bir ifadenin yanı sıra bir görsel, bağlantı ya da video içeriği de yer almaktadır. Ayrıca sonuçlara göre içerik türü olarak Ankara'daki halk kütüphanesi paylaşımlarının önemli bir bölümünde görsel içeriği bulunmaktadır. Bununla birlikte bulgularda kütüphanelerin Facebook sayfalarındaki gönderi sayılarının 2017 yılından itibaren dikkate değer oranda artış gösterdiği tespit edilmiştir. Bu artışta Facebook sayfasını 2018 yılında açan Adnan Ötüken İl Halk Kütüphanesinin diğer kütüphanelere göre çok daha fazla sayıda gönderi paylaşmasının etkili olduğunu söyleyebiliriz Konu çerçevesinde Tablo 1'deki veriler incelendiğinde kütüphanelerin Facebook sayfalarında paylaştıkları gönderi sayılarının önemli ölçüde farklılık gösterdiği anlaşılmakta; belirli kütüphanelerin Facebook sayfaların kullanım örüntülerinin bulgulara yön verdiği ortaya çıkmaktadır. Bununla birlikte 2019 yılı Temmuz ayı verileri itibariyle Ankara'daki halk kütüphanelerinin gönderi sayıları önceki yıllardaki gönderi sayılarından daha fazladır. Gönderilerin paylaşıldığı aylar açısından elde edilen bulgular değerlendirildiğinde ise Ağustos ve Eylül aylarındaki paylaşımların diğer aylara oranla daha düşük olduğu, en yüksek paylaşımın ise Mart ayında olduğu tespit edilmiştir. Mart ayındaki bu artışın her yıl Mart ayının son haftasında düzenlenen Kütüphane Haftası etkinliklerine yönelik gönderilerden kaynaklandığını söyleyebiliriz. Gönderiler haftanın günleri açısından incelendiğinde ise paylaşım sayılarının hafta sonunda düşüş gösterdiği anlaşılmaktadır. En fazla gönderinin paylaşıldığı günler Pazartesi ve Çarşamba günleridir. Gönderilerin saat bazındaki sıklıkları ise genelde yoğunluğun mesai saatleri içerisinde olduğunu göstermektedir. Bu bağlamda özellikle 10.00 ile 17.00 arasındaki gönderilerin sıklığı diğer saatlere göre daha fazladır.

Ankara'daki halk kütüphanelerinin Facebook sayfalarındaki gönderiler kullanıcı etkileşimleri açısından değerlendirilmesinde beğeni, paylaşım ve yorum şeklindeki etkileşimler dikkate alınmıştır. Bu etkileşimin sayısal boyutunda sayfayı takip eden kullanıcı sayısı ve gönderinin ulaştığı kişi sayısının da etkili olduğunu söylemek mümkündür. Diğer taraftan etkileşim şekline yönelik bulgular kullanıcıların yoğunlukla beğeniler aracıllğıyla etkileşimi tercih ettiklerini göstermiş̧ir. Nitekim 1739 gönderinin yaklaşı üçte ikisi $(\% 65,5)$ hiçbir kullanıcı tarafından paylaşılmamış, \%89'u ise hiç yorum almamıştır. Buna karşın hiç beğeni almayan gönderi sayısı \%10,2'dir. Bu durumun oluşmasında sayfanın takipçi sayısı, gönderinin ulaştığ1 kişi sayısı, gönderi içeriğinin ve kullanıcı davranışlarının etkili olduğu düşünülmektedir. Araştırmanın yöntem bölümünde belirtilen birinci araştırma sorusuyla (S1) 
da bağlantılı olan bu konuda ortaya çıkan sonuç literatürdeki bazı çalışmalarla da benzeşme göstermektedir. Bununla birlikte kütüphanelerin gönderilerinin yaklaşık \%40'l1k bölümü en fazla beş beğeni almıştır. Gönderilerin üçte birlik bölümü ise en fazla beş yoruma sahiptir. $\mathrm{Bu}$ sonuçlar kütüphanelerin kullanıcı etkileşimlerinin yukarıda belirtilen nedenlerden de kaynaklı olarak görece düşük olduğu şeklinde yorumlanabilir.

Araştırmadaki ikinci soru kapsamında elde edilen sonuçlar (S2) ise Ankara'daki halk kütüphanelerinin gönderilerinin almış olduğu etkileşimler beğeni bazında değerlendirildiğinde 2018 ve 2019 yılının Temmuz ayına kadar paylaşılan gönderilerin aldığı beğeni sayısı diğer yıllara oranla daha yüksektir. Bu durumda da 2018 yılında açılan sayfaların ve araştırmamızdaki en fazla gönderi paylaşımına sahip kütüphane olan Adnan Ötüken İl Halk Kütüphanesinin paylaşımlarının etkili olduğu düşünülmektedir. Aylar bazında ise Mart, Nisan, Ocak, Şubat, Aralık ve Kasım aylarındaki gönderiler daha fazla beğeni almıştır. Paylaşılan gönderi sayısının çokluğuna göre Haziran ayında bir düşüşün gözlendiği sonuçlar, Ağustos ve Eylül aylarının gerek paylaşım sayısı gerekse beğeni sayısı olarak en düşük oranların elde edildiği aylardır. Sonuçlara göre yaz aylarındaki etkileşim ve gönder sayıları düşüktür. Buna karşın öğretim ve eğitim döneminde artan gönderilerle birlikte beğeni sayıları da yükselmektedir. Günlere göre gönderilerin etkileşim sayılarına ilişkin sonuçlar ise Cumartesi, Pazar ve Pazartesi günleri paylaşılan gönderilerin aldıkları beğeni sayılarının düşük olduğunu ortaya koymuştur. Bulgularda özellikle Pazartesi günü paylaşılan gönderi sayısının haftanın bazı günlerinden daha yüksek olmasına karşın alınan beğeni sayısı düşüktür. Bulgulara göre Çarşamba ve Perşembe günleri paylaşılan gönderiler en fazla beğeniyi almıştır. Salı ve Cuma günleri ise paylaşılan gönderi sayıları ve alınan beğeni sayıları birbirine yakındır. Kütüphanelerin gönderileri saat bazında incelendiğinde ise saat $16.00-17.00$ ve $12.00-13.00$ aralığında paylaşılan gönderilerin daha fazla beğeni aldığı görülmektedir. $\mathrm{Bu}$ sonuçta etkinliklerden sonra paylaşılan gönderilerin etkisinin olduğu düşünülmektedir.

Araştırmadaki üçüncü soru (S3) çerçevesinde yapılan metin işleme uygulamaları ve analizleri çerçevesinde ilk aşamada beş temel konu kategorisi saptanmıştır. Gönderilerin gözle incelenmesi sonucunda oluşturulan bu kategoriler, etkinlik, hizmet, koleksiyon, anma, kutlama ve teşekkür mesajları ile tanıtım ve farkındalık oluşturma başlıklarını taşımaktadır. Söz konusu kategorilerin alt konularının belirlenmesi için de her bir kategori için kelime bazında bi-gram analizi yapılarak kelime çiftlerinin gönderilerde geçiş sıklıkları belirlenmiştir. Buna göre etkinlik kategorisinde yer alan gönderilerde masal ve kitap okuma, kütüphanede yarıyıl program1, oryantasyonlar, gibi etkinliklere yer verildiği dikkati çekerken belirli gün ve haftalarda düzenlenen etkinliklere (Dünya Çocuk Kitapları Haftası, Kütüphane Haftası gibi) yönelik etkinlik gönderilerinin de paylaşıldığı görülmüşsür. Ancak genel olarak değerlendirildiğinde kelime çiftlerinin geçiş sıklıklarından kütüphanelerin etkinlik ile ilgili gönderilerinde çoğunlukla gençleri ve çocukları hedeflediklerini söyleyebiliriz. Bu bulgunun 2017 yılında Joo ve Lu (2017) tarafından yapılan çalışmada elde edilen sonuçlarla örtüştüğü dikkati çekmektedir. Kutlama, anma ve teşekkür mesajlarına yönelik gönderilerde de İstiklal Marşı'nın kabulü, 23 Nisan Ulusal Egemenlik ve Çocuk Bayramı, 19 Mayıs Atatürk'ü Anma, Gençlik ve Spor Bayramı ile 10 Kasım Atatürk'ü Anma Günü gibi özel günlere ve bayramlara yönelik içerikler sunulmaktadır. Az sayıda gönderinin paylaşıldığı kategorilerden biri olan koleksiyon kategorisinde yer alan içerikler genellikle haftanın kitapları, çocuk kitapları ve 
kütüphaneye yeni gelen kitapların tanıtımı odağında sunulmaktadır. Genellikle kitap türü materyallere yönelik gönderilerin yer aldığı bu kategoride ayrıca hizmet kategorisiyle de bağlantılı olabilecek ödünç alma hizmetine yönelik bilgilendirmelerin yapıldığı saptanmıştır. Hizmet kategorisindeki gönderilere yönelik analizlere göre bu kategoride genellikle kütüphanenin mevcut kullanım durumuna ilişkin bilgilendirmeleri, ödünç verme hizmetlerini, web sitesi ve sosyal medya duyuruların içeren gönderiler bulunmaktadır. Son olarak tanıtım ve farkındalık oluşturma kategorisindeki gönderilerde ise kütüphane kullanımı ve okumayla ilgili teşvik, sosyal medya hesaplarına ve web sayfalarına yönelik tanıtım gibi amaçlar öne çıkmıştır.

Araştırmada sunulan sonuçlar doğrultusunda Ankara'daki halk kütüphanelerinin Facebook sayfalarındaki içeriklerle ilgili şu önerilere yer verilmektedir:

- Kütüphanelerin gönderilerinde etkileşimin yüksek olduğu zaman aralkklarını değerlendirmeleri kullanıcı kitlesinin beklenti ve davranışlarını anlama açısından önem taşımaktadır.

- Kütüphanelerin gönderilerinde yaş gruplarına göre farklılık gösteren etkinliklerin belirlenmesi ve bu doğrultuda gönderilerin yapılandırılması yeni takipçilere ulaşmalarında etkili olacaktır.

- Kütüphanelerin koleksiyonlarına yönelik gönderileri artırırken koleksiyonlarındaki farklı kaynak türlerini de öne çıkaracak içerikler paylaşmaları kullanıcıların farklı kaynaklarla etkileşimini geliştirecektir.

- Hizmetlere yönelik gönderilerde işletimsel (açık ve kapalı olduğu saatleri kullanım koşulları gibi) hizmetlerin yanı sıra sunulan diğer hizmetlerin daha fazla vurgulanması kullanıcıların kütüphane hizmetlerinden daha fazla haberdar olmalarında ve hizmetlere yönelik geri bildirimde bulunmalarında etkili olacaktır.

- Tanıtım ve farkındalık oluşturma kategorisinde kütüphanelerin üçüncü mekan bağlamında sosyal etkileşim ortamı olma işlevlerine yönelik veya güncel toplumsal olaylara yönelik farkındalık çalışmaları gönderilerinin paylaşılması hem takipçi kitlesi oluşturma hem de kullanıcı etkileşimini artırmaya katkı sağlayacaktır.

Siralanan öneriler doğrultusunda toplumun farklı kesimlerine hizmet sunan kurumlar olan halk kütüphanelerinin gönderilerinde bu çeşitliliğe göre bir sosyal medya politikası çerçevesinde hareket etmeleri gereklidir. Bu politika çerçevesinde belirlenecek olan hedef kitlelere uygun içerik oluşturma çalışmaları kullanıcı etkileşimini de artıracak; ayrıca kütüphane paylaşımlarını düzenli takip eden bir topluluğun da oluşturulmasını sağlayacaktır. Bununla birlikte kütüphanelerin genel anlamda sosyal medya platformlarındaki gönderilerine yönelik etki değerlendirme çalışmalarını bu platformlarda ürettikleri veriler üzerinden yapmaları ve bu çalışmaları belirli zaman aralıklarında tekrarlayarak stratejilerine yön vermeleri değişen kullanıcı beklenti ve davranışlarını belirlemek açısından önerilmektedir. Bu çerçevede gelecek çalışmalarda daha fazla sayıdaki kütüphaneye ilişkin olarak toplanacak sosyal medya verileri ile yapılacak analizlerin ülkemizdeki kütüphanelerin sosyal medya etkileşim örüntüsünü yansıtacağı düşünülmektedir. 


\section{Kaynakça}

Abdullah, N., Chu, S., Rajagopal, S., Tung, A. ve Kwong-Man, Y. (2015). Exploring libraries' efforts in inclusion and outreach activities using social media. Libri 65(1), 34-47. doi:10.1515/libri2014-0055

Aharony, N. (2010). Twitter use in libraries: An exploratory analysis. Journal of Web Librarianship, 4(4), 333-350. doi:10.1080/19322909.2010.487766

Aharony, N. (2012). Facebook use in libraries: An exploratory analysis. Aslib Proceedings: New Information Perspectives, 64(4), 358-372. doi:10.1108/00012531211244725

Akbaş, M. ve Fenerci, T. (2016). Üniversite kütüphanelerinde sosyal medya politikaları. Bilgi Dünyası, 17(2), 201-231. doi:10.15612/bd.2016.518

Albarran, A. B. (2013). Introduction. A. B. Albaran (Ed.), The Social Media Industries içinde (s. 115). New York: Routledge. doi:10.4324/9780203121054

Anttiroiko, A. V. ve Savolainen, R. (2011). Towards library 2.0: The adoption of Web 2.0 technologies in public libraries. Libri, 61(2), 87-99. doi:10.1515/libr.2011.008

Aras, B. B. (2014). University libraries and social media policies. Journal of Balkan Libraries Union, 2(1), 21-27. doi:10.16918/bluj.58547

Aras, B. B. ve Çolaklar, H. (2015). The role of social media in the promotion of university libraries. Journal of Library and Information Sciences, 3(2), 79-105. doi:10.15640/jlis.v3n2a5

Berthold, M. R., Cebron, N., Dill, F., Gabriel, T. R., Kötter, T., Meinl, T., ... Wiswedel, B. (2009). KNIME - the Konstanz information miner: Version 2.0 and beyond. ACM SIGKDD Explorations Newsletter, 11(1), 26-31. doi:10.1145/1656274.1656280

Blakeman, K. ve Brown, S. (2010). Part II: Social media: Essential for research, marketing and branding. Bulletin of the American Society for Information Science and Technology, 37(1), 4750. doi:10.1002/bult.2010.1720370121

Bodnar, J. ve Doshi, A. (2011). Asking the right questions: A Critique of Facebook, social media, and libraries. Public Services Quarterly, 7(3-4), 102-110. doi:10.1080/15228959.2011.623594

Bughin, J. (2008). The rise of enterprise 2.0. Journal of Direct, Data and Digital Marketing Practice, 9, 251-259. doi:10.1057/palgrave.dddmp.4350100

Chalon, P. X., Di Pretoro, E. ve Kohn, L. (2008). OPAC 2.0: Opportunities, development and analysis. 11th European Conference of Medical and Heakth Libraries içinde (s.1-11). Erişim adresi: http://eprints.rclis.org/12136/

Chen, D. Y. T., Chu, S. K. W. ve Xu, S. Q. (2012). How do libraries use social networking sites to interact with users. Proceedings of the ASIST Annual Meeting, 49(1), 1-10. doi:10.1002/meet.14504901085

Collins, G. ve Quan-Haase, A. (2012). Social media and academic libraries: Current trends and future challenges. Proceedings of the ASIST Annual Meeting, 49(1), 1-4. doi:10.1002/meet.14504901272

Doğan, S. (2006). Türkçe dokümanlar için n-gram tabanlı sinıflandırma: Yazar, tür ve cinsiyet. (Yayımlanmamış yüksek lisans tezi). Yıldız Teknik Üniversitesi, İstanbul.

Evjen, S. ve Audunson, R. (2009). The complex library: Do the public's attitudes represent a barrier to institutional change in public libraries? New Library World, 110(3/4), 161-174. doi:10.1108/03074800910941356

Fernandez, J. (2009). A SWOT analysis for social media in libraries. Online, Sep-Oct, 35-37. Erişim adresi: 
https://digitalcommons.library.umaine.edu/cgi/viewcontent.cgi?article=1004\&context=lib_staff pub

Gavrilis, D., Kakali, C. ve Papatheodorou, C. (2008). Enhancing library services with web 2.0 functionalities. Lecture Notes in Computer Science: Cilt: 5173 (s.148-159) içinde. doi:10.1007/978-3-540-87599-4_16

Hallahan, K., Holtzhausen, D., van Ruler, B., Verčič, D. ve Sriramesh, K. (2007). Defining strategic communication. International Journal of Strategic Communication, 1(1), 3-35. doi:10.1080/15531180701285244

Houk, K. M. ve Thornhill, K. (2013). Using Facebook page insights data to determine posting best practices in an academic health sciences library. Journal of Web Librarianship, 7(4), 372-388. doi: $10.1080 / 19322909.2013 .837346$

Joo, S., Choi, N. ve Baek, T. H. (2018). Library marketing via social media: The relationships between Facebook content and user engagement in public libraries. Online Information Review, 42(6), 940-955. doi:10.1108/OIR-10-2017-0288

Joo, S. ve Lu, K. (2017). Content analysis of facebook posts in public libraries based on textual analysis. Proceedings of the Association for Information Science and Technology, 54(1), 718719. doi:10.1002/pra2.2017.14505401129

Keleş, E. (2017). Ankara'daki üniversite kütüphanelerinin Twitter hesap analizi. Türk Kütüphaneciliği, 31(3), 374-393. Erişim adresi: http://www.tk.org.tr/index.php/TK/article/view/2822/2757

Kim, Y. M. ve Abbas, J. (2010). Adoption of Library 2.0 functionalities by academic libraries and users: A knowledge management perspective. Journal of Academic Librarianship, 36(3), 211218. doi:10.1016/j.acalib.2010.03.003

Krippendorff, K. (2004). Content analysis: An introduction to its methodology (2. bs.). Londra: SAGE Publications.

Kronqvist-Berg, M. (2014). Social media and public libraries exploring information activities of library professionals and users. Åbo: Åbo Akademis Forlag.

Lewis, B. K. ve Nichols, C. (2013). Attitudes and perceptions about social media among college students and professionals involved and not involved in strategic communications. H. S. N. AlDeen ve J. A. Hendricks (Ed.), Social media usage and impact içinde (s. 129-143). Lanham: Lexington Books.

Long, M. C. (2013). Social media as a tool for consumer engagement. H. S. N. Al-Deen ve J. A. Hendricks (Ed.), Social media: usage and impact içinde (s. 145-159). Lanham: Lexington Books.

Özel, C. (2018). Sabancı Üniversitesi Bilgi Merkezi’nin bakışıyla sosyal medya ve kütüphaneler. Türk Kütüphaneciliği, 32(1), 40-45. Erişim adresi: http://www.tk.org.tr/index.php/TK/article/view/2904/2816

Patel, L. (2010). The rise of social media. $T$ and $D$. doi:10.4324/9781315563312-21

Rieder, B. (2013). Studying Facebook via data extraction: The netvizz application. Proceedings of the 5th Annual ACM Web Science Conference, WebSci'13 içinde (s. 346-355). New York: Association for Computing Machinery. doi:10.1145/2464464.2464475

Shiri, A. ve Rathi, D. (2013). Twitter content categorisation: A public library perspective. Journal of Information and Knowledge Management, 12(4), 1350035-1-1350035-8. doi:10.1142/S0219649213500354 
Social Media. (2019). Gartner Glossary: Intformation Tehcnology. Erişim adresi: https://www.gartner.com/en/information-technology/glossary/social-media

Solomon, L. (2013). The Librarian's nitty-gritty guide to social media. Chicago: American Library Association.

Şeker, S. E. (2011, 23 Nisan). N-gram. [Blog yazısı]. Erişim adresi: http://bilgisayarkavramlari.sadievrenseker.com/2011/04/23/n-gram/

Tavluoğlu, C. (2013). Üniversite kütüphanelerinde web 2.0 araçlarının kullanımı. (Yayımlanmamış yüksek lisans tezi) Hacettepe Üniversitesi, Ankara.

Winn, D., Rivosecchi, M., Bjerke, J. ve Groenendyk, M. (2017). MTL 2.0: A report on the social media usage and user engagement of the "Big Four" academic libraries in Montréal. Journal of Academic Librarianship, 43(4), 297-304. doi:10.1016/j.acalib.2017.04.006

Wright Joe, J. (2015). Assessment of social media in the library: Guidelines for administrators. Journal of Library Administration, 55(8), 667-680. doi: 10.1080/01930826.2015.1085251

$\mathrm{Xu}, \mathrm{C}$., Ouyang, F. ve Chu, H. (2009). The academic library meets web 2.0: Applications and implications. Journal of Academic Librarianship, 35(4), 324-331. doi:10.1016/j.acalib.2009.04.003

Yalçın, H. (2014). Sosyal ă̆lar ve bilgi hizmetleri: Ă̆ kuşağının kütüphanelerden beklentileri. (Yayımlanmamış doktora tezi). Hacettepe Üniversitesi, Ankara.

Young, S. W. H. ve Rossmann, D. (2015). Building library community through social media. Information Technology and Libraries, 34(1), 20-37. doi: 10.6017/ital.v34i1.5625

Zohoorian-Fooladi, N. ve Abrizah, A. (2014). Academic librarians and their social media presence: A story of motivations and deterrents. Information Development, 30(2), 159-171.

doi:10.1177/0266666913481689 


\section{Summary}

Social media is a concept that alters approximately every sector. The use of the concept shows a variety depending on the fields that social media tools implemented. It is seen that concepts such as library 2.0 and OPAC 2.0 are used in the literature of library and information science (Bughin, 2008; Chalon, Di Pretoro ve Kohn, 2008; Gavrilis, Kakali ve Papatheodorou, 2008).

Libraries attempt to establish strategies to develop content and present them in the most convenient form for the users. The content produced by libraries on social media platforms also provides an open pool of records related to the services offered, the topics promoted, and the activities. It is also possible to record the services and activities registered with much official correspondence in the institutional functioning of the libraries through social media posts without any bureaucratic process and in more detail. Social networking sites, especially Facebook and Twitter, are mostly used platforms among the many other social media tools. It is seen in many studies in the literature that libraries are analyzed in terms of their post contents on Facebook and Twitter, and their interaction patterns are detected (Aharony, 2010, 2012; Chen, Chu ve Xu, 2012; Wright Joe, 2015).

This study aims to analyze user interactions of public libraries in Ankara based on the posts published on their Facebook pages. In line with this aim, Facebook posts and user interactions with the posts of ten public libraries are analyzed. Two methods were used in this study. Firstly, interaction data obtained from posts were presented with descriptive statistics. Secondly, posts were categorized with text processing approaches. The following research questions were investigated in this study:

RQ1: How public libraries in Ankara interact with their users via Facebook pages and posts?

RQ2: Based on the time frames, which posts of public libraries in Ankara receive more likes?

RQ3: What kind of contents are posted on Facebook pages of public libraries in Ankara?

According to the findings in which the 1739 posts were analyzed, the posts usually contain a textual expression as well as a visual, link, or video content. Findings reveal that most of the posts contain images. It is detected that the content shared by libraries on Facebook pages has significantly increased since 2017. As of July 1, 2019, the number of posts is higher than those of previous years. Furthermore, nearly two-thirds $(65.5 \%)$ of posts were not shared by any user, and $89 \%$ of posts received no comments. It was determined that $10.2 \%$ of posts that did not receive any like. Concerning with RQ1, this result reflects that users' interactions are mostly based on likes

The results obtained in the scope of RQ2, the posts received by the public libraries in Ankara until 2018 and July 2019 are higher than the previous years. The number of interactions and posts in the summer months is low. The number of posts and received likes increases during the school period of the year. Posts shared on Saturday, Sunday, and Monday have a low number of likes. However, results reflect that the posts shared between 16.00-17.00 and 12.0013.00 received more likes.

Regarding the third research question (RQ3), five basic subject categories were identified in the first stage. These categories are events, services, collections, memorials, celebrations, 
and thanks messages, and promotion and awareness-raising. In the second stage, bi-gram tests were employed for each category to detect sub-categories. Posts in the event category consist of library names, thanks messages, and events organized on special days and weeks. In general, the event category includes semester program, orientations, book reading, and fairy tale. The celebration, memorial, and thank you messages are mostly related to special days and holidays. The collection category, in which few posts are shared, includes the posts about the books of the week, children's books, and new books. Plus, library operations, loan services, and announcements are classified under the service category. Lastly, posts related to promoting library use and reading, social media, and web page promotion have come to the fore in the promotion and awareness category.

In conclusion, public libraries, which are institutions that serve different segments of the society, should also act within the framework of a social media policy that considers this diversity. At this point, developing strategies to increase the visibility of the posts will increase user interaction. Additionally, it is recommended that libraries should conduct impact assessment studies based on the data they produce on social media platforms. It is also essential to develop strategies by repeating impact assessments at certain time intervals in order to understand the changing user expectations and behaviors. 